\title{
Abhandlung
}

Nicolò Marchetti, Abbas Al-Hussainy, Giacomo Benati, Giampaolo Luglio, Giulia Scazzosi, Marco Valeri and Federico Zaina

\section{The Rise of Urbanized Landscapes in Mesopotamia: The QADIS Integrated Survey Results and the Interpretation of Multi-Layered Historical Landscapes}

https://doi.org/10.1515/za-2019-0016

\begin{abstract}
This paper draws on the preliminary results of the QADIS survey project, conducted by the University of Bologna and the Iraqi State Board of Antiquities and Heritage since 2016 in the Qadisiyah province. The project addresses phenomena related to anthropogenic transformation of landscapes in a region that was at the core of the early Mesopotamian urbanization process. Building upon the seminal work conducted by R. McC. Adams in the 1960 s and 1970 s, we implemented an integrated documentation technique to reconstruct at regional levels the changes in the dense network of human settlements and artificial water infrastructures characterizing the evolution of this archaeological landscape over time. The aim of the article is that of providing a finer-grained regional picture of $4^{\text {th }}$ and $3^{\text {rd }}$ millennium $\mathrm{BC}$ urban developments which can be useful for better conceptualizing the scale and pace of early Mesopotamian urbanism.
\end{abstract}

Keywords: survey, remote sensing, landscape archaeology, urbanized landscapes, settlement pattern, Southern Mesopotamia

\section{Introduction (NM)}

One of the main objectives of the QADIS survey project in central Mesopotamia (Fig. 1) is to understand the complex interplay between the spatial clustering of human communities and the development of irrigated farmland in an otherwise semi-arid environment. These appear indeed to be the main variables in the southern Mesopotamian

\footnotetext{
*Corresponding author: Nicolò Marchetti, Department of History and Cultures, University of Bologna, Bologna, Italy; Email: nicolo.marchetti@unibo.it

Abbas Al-Hussainy, College of Archaeology, Qadisiyah University, Diwaniyah, Iraq

Giacomo Benati, Department of History and Cultures, University of Bologna, Bologna, Italy

Giampaolo Luglio, Department of Classics, Sapienza University of Rome, Rome, Italy

Giulia Scazzosi, Department of Humanities, University of Pavia, Pavia, Italy

Marco Valeri, Department of History and Cultures, University of Bologna, Bologna, Italy

Federico Zaina, Department of History and Cultures, University of Bologna, Bologna, Italy
}

eco-social system during much of its history and are thus central to our understanding of the processes of formation, development and decline of urban centers starting in the $4^{\text {th }}$ millennium BCE (cf. Widell et al. 2013, 66 f.). Robert McCormick Adams' surveys in southern Mesopotamia (1965; 1981; Adams/Nissen 1972) were carried out according to standards that were unparalleled for the time. He used a set of aerial photographs from 1961 to locate potential sites and map canals whose traces were visible on the surface. He was systematic in recording sites and above all, he was acutely aware of the historiographical potential of his survey work, which resulted in a powerful interpretation of settlement patterns and hydraulic activities (Adams 1981). After a long halt to fieldwork resulting from political instability, archaeological researches have resumed in southern Iraq in recent years but with surveys mostly confined as to being preliminary to excavation projects. The need to begin filling current spatial and temporal voids guided us in designing the research strategy of our survey project (§ 2).

In 2016, we started a new 3-year project aiming at investigating settlement dynamics in a region currently 
extending over $1829 \mathrm{~km}^{2}$ (down from an initial $2457 \mathrm{~km}^{2}$, cf. the Acknowledgments) around Adab and Puzrish-Dagan, an area which appears indeed to have been a major urban formation core from early prehistory to the later historical periods. We have carried out six campaigns as of October 2018. Adams included this area in his field surveys (he recorded 415 sites within it, although he limited himself mostly to uncultivated areas). In this paper, we discuss the preliminary results of the 2016 to 2018 QADIS survey seasons, focusing on the data relevant for the $4^{\text {th }}$ and $3^{\text {rd }}$ millennium BCE, i. e. the period corresponding to the first urbanization wave in early Mesopotamia. We not only now face a landscape greatly changed in the last four decades because of the intensification of agricultural exploitation and the continuous digging of new canals, but also the disastrous looting of sites which took place mainly between 2003 and 2007 (Emberling/Hanson 2008; Marchetti et al. 2018; Otto et al. 2018) - and has not been completely halted. This phenomenon left deep scars on the landscape, to the point that in remote sensing some of the new sites are being revealed by the presence of looting pits visible in satellite imagery. An unexpected correlate of this situation is the eye-popping abundance of ceramic materials on the surface of looted sites. This on the one hand forces us to somewhat limit the picking up of sherds, on the other it entails that we are now often dealing with almost complete pottery shapes from assemblages deriving from excavations (if uncontrolled), i. e. datasets which may be functionally as well as chronologically meaningful in terms of the interpretation of surface structural evidence in the case of large urban sites with single phases of occupation in a given sector.

\section{State of the Art and Research Questions}

\subsection{Landscape archaeology and the question of Mesopotamian urbanism: Previous studies (GB)}

The Mesopotamian early urban phenomenon ( $4^{\text {th }}$ millennium BCE) is a hotly debated topic in the field of ancient Near Eastern studies and a classic source of comparative evidence for global studies on urbanism (see Adams 1966; Butterlin 2018; Trigger 2003; Stein/Rothman 1994). There are two main reasons for this. One is the antiquity of the phenomenon, now known to possibly date at least as far back as the Late Chalcolithic 2-3 period (ca. 4200-3700
BCE) in the Khabur region of modern Syria (Al-Quntar et al. 2012). The other reason is the amount of archaeological work focusing on Mesopotamian urbanism done over the last decades, indeed staggering (but cf. § 1), if we consider the sheer amount of studies on settlement patterns, urban site archaeology and material culture carried out, and the workshops and conferences organized over the years (Iamoni 2016b). During the last two decades, in particular, archaeologists and anthropologists interested in this phenomenon have worked on a series of field projects in the northern part of the Mesopotamian alluvium, western Syria and, lately, Iraqi Kurdistan, in order to retrieve more information on what was once dismissed as a "periphery" of the Mesopotamian core, which is identified with historical Sumer in southern Mesopotamia - present-day south-central Iraq -, the "heartland of cities" (Stein 2012).

The complexity of the political scenario of modern Iraq after 1991 severely hampered international research cooperation in the field. Only after 2011 could international fieldwork finally be resumed in southern Iraq. The result is an extremely diverse and unbalanced situation. On the one hand, the investigation of archaeological sites and landscapes in Syria and Iraqi Kurdistan has been enjoying unprecedented attention. Experimentation with modern surveying and excavating techniques in this region has yielded substantial new datasets (Kopanias/ MacGinnis 2016). On the other hand, however, a lack of adequate publication methods, the enormous backlog in the publication of final reports, and the virtual absence of comparable datasets from southern Mesopotamia still deprives scholars of readily available tools for producing new models and explanations for early urban phenomena in this area (cf. Kintigh et al. 2014, 19).

What we can glean from preliminary reports and available datasets is that we are dealing here with a particularly heterogeneous and differently paced phenomenon. The primary urban formation process has been, at first, interpreted as driven by the emergence of urban and state societies in the southern alluvium (Algaze 1993). This picture, however, underwent considerable reconsideration in recent years (Stein 2012, 125). Lawrence/Wilkinson $(2015,329)$ distinguish two phases for the Upper Mesopotamian urban phenomenon: The first during the Late Chalcolithic period (4000-3000 BCE; hereafter LC) the second during the Early Bronze Age (2600-2000 BCE; hereafter EBA). Recent investigations in the Syrian Khabur region have documented the slow growth of population densities at regional level that resulted in the formation of urban enclaves extending over hundreds of hectares as early as the LC 2-3 periods (Al-Quntar et al. 2012; Al-Quntar 2016; Al-Quntar/Abu Jayyab 2014; Lawrence/ 
Wilkinson 2015, 331, fig. 2). Investigations in the area of Erbil and along the Tigris watershed have documented a completely different settlement pattern for the LC period, with no trace of large urban sites (Peyronel et al. 2016; Peyronel/Vacca 2015; Morandi Bonacossi/Iamoni 2015; Iamoni 2016a; Skuldbøl/Colantoni 2016). This first phase of Upper Mesopotamian urbanism underwent a deep crisis at the very end of the LC 3 (ca 3600 BCE) with evidence of large-scale conflict and widespread destructions (Stein 2012, 14; Butterlin 2018, fig. 265). The subsequent LC 4-5 periods witnessed a gradual increase of interaction between the Upper Mesopotamia and the southern plains, first along the axis established along the lower Tigris, the Zagros piedmont and southern Khuzistan (Stein 2012, 141f.; Stein et al. 1996; Minc/Emberling 2016; Pittman/ Blackman 2016), then along the Euphrates basin, with the establishment of a network of "enclaves" in the middle Euphrates region and an enormous diffusion of southern Mesopotamian material culture in neighboring regions, the so-called "Uruk Expansion”. The whole Upper Mesopotamian urban system collapsed towards the end of the 4th millennium BCE, in connection with a major aridification event (Staubwasser/Weiss 2006), only to be renovated during the second quarter of the 3rd millennium BCE (Ristvet 2017, 38-40), generally dubbed as "second urban revolution" (Lawrence/Wilkinson 2015, 333, fig. 4). The second urbanization, however, differs markedly from the first one (Lawrence/Wilkinson 2015, 334). EBA urban sites developed (and collapsed) rapidly around the mid-3rd millennium BCE and differed in terms of size, spatial organization, settlement layout and population dynamics from their LC forerunners (Lawrence/Wilkinson 2015, 334).

These studies not only introduced new datasets and models, but also a variety of new archaeological techniques: intensive and extensive landscape surveys, satellite imagery and, more recently, drone imagery, extensive and intensive excavation, archaeometric testing of finds, paleobotanical analyses, etc. By contrast, historical urban trends in southern Mesopotamia are still modeled on the 1960s-1970 s survey projects, with recent contributions from new datasets derived from the study of satellite imagery (Hritz, 2010; Pournelle 2003; Ur 2013a; Wilkinson 2003; Wilkinson et al. 2013). The resulting picture is that of an unfulfilled potential, especially with regard to the new research questions arising from this wave of fresh investigations in the northern alluvium, and new methodologies from other research areas (cf. Banning et al. 2017; M.E. Smith 2014; M.L. Smith 2014).

At present, our understanding of southern Mesopotamian pathways towards urbanism can be framed only sketchily. For much of the $5^{\text {th }}$ millennium BCE, humid climatic conditions and the high level of the Gulf caused the formation of a marshy environment in the southern alluvium, where the settlements were built upon higher ground - "turtlebacks" - and scattered in the midst, or at the margins, of marshlands (Butterlin 2018, figs. 95-96, 165). The $4^{\text {th }}$ millennium BCE witnessed a trend towards a cooler and more arid climate that drove a progressive progradation of the Tigris-Euphrates delta (Brooks 2006, $37 \mathrm{f}$; B Butterlin 2018, $329 \mathrm{f}$., fig. 362). This climatic trend seemingly triggered niche-construction mechanisms consisting of site nucleation along levee-systems and irrigation agriculture through levee-breaking strategies, that, in turn, fueled the growth of urban centers (Brooks 2006, 37 f.; Nissen 1988, 65-69; Wilkinson 2003; Wilkinson et al. 2015). The growth of urban enclaves in the southern alluvium occurred in three major stages between the second half of the $4^{\text {th }}$ millennium BCE (LC 4-5) and the first half of the $3^{\text {rd }}$ millennium BCE (Early Dynastic I and Early Dynastic III periods) and was seemingly coupled with the virtual disappearance of small sites (Nissen 1988, 70-72; Wilkinson et al. 2013). Rough estimates, indeed, indicate that by the mid-3rd millennium BCE $80 \%$ of the population clustered in sites of 40ha or more (Ur 2013b, 141), while the rural landscape was being transformed into an almost completely artificial network of waterways and cultivation zones (Rost 2017, 9, fig. 3).

These general trends are certainly important, but need testing and validation on the ground. Also, urban-rural relationships are much underdeveloped topics for southern Mesopotamia (cf. Widell et al. 2013, 66). For a number of reasons, Mesopotamian archaeologists traditionally focused on large sites, and urban built landscapes, neglecting subsistence landscapes and urban hinterlands. Only recently, scholars have rekindled attention on non-urban economies, land use, population dynamics, urban-hinterland relationships (Wilkinson et al. 2013; Lawrence/Wilkinson 2015; Lawrence et al. 2016). In addition, recent comparative and cross-cultural studies stressed the importance of scale for understanding urban development (Ortman et al. 2014; 2016; 2017; Altaweel/Palmisano 2019; Arcaute et al. 2015; Bettencourt et al. 2007). Therefore, we deemed it important to focus on issues connected to scale and urban-hinterland relationships in structuring a new fieldwork project that targeted southern Mesopotamian urbanism from a regional perspective (cf. M. L. Smith 2014). 


\subsection{Current research questions and research goals (NM - GB)}

This complex research landscape invites several questions:

1) What kind of feedback mechanisms between human communities and their natural landscape triggered urban growth and site nucleation during the $4^{\text {th }}$ and $3^{\text {rd }}$ millennium BCE?

2) How did the transition from non-urban to urban lifeways affect the environment as well as the lifeways of human communities?

3) What was the scale and the pace of urban development in the study area? Do general trends gleaned from previous research apply to the region taken into examination?

With these premises in mind, and facing the possibility of embarking on a new archaeological exploration of southern Iraq, we are pursuing the following objectives:

1) Testing on the ground the validity of the historical trends sketched by Adams himself and Adams-related researches for the $4^{\text {th }}$ and $3^{\text {rd }}$ millennium BCE.

2) Building a methodology that is able to capture as fully as possible natural and man-made changes in the Iraqi historical landscape, in order to reconstruct the dynamic relationship between human communities and their environment.

3) Focusing both on settlement patterns - including secondary sites and the hinterland of large urban centers - and on hydraulic and agricultural landscapes.

4) Building new models of urban formation in a core area of southern Mesopotamia and comparing them with the regional trends in the northern alluvium.

\section{Research Framework: The Qadis Survey Project}

\subsection{Research design (NM - FZ)}

In spite of remarkable technological progress over the past decades and the availability of an impressive array of aerial and satellite imagery, the methodological mainstays of archaeological field surveys in Mesopotamia are still those defined by Adams (1965; 1981) and Wilkinson (2003): remote sensing, surface material collection, and geoarchaeological study of sediments (Stein 2015; Ur/ Ertsen 2015). The degree of accuracy in this field is meas- ured by the ratio of survey detail to the total surface of the surveyed area.

In this light, one of the main goals of the QADIS project is to update the bulk of Adams' results through a research strategy aimed at producing a new understanding of the multi-layered historical landscape of a region by means of integrated documentation techniques. The envisaged research design combines a set of techniques in a backto-back protocol in order to: a) plot - in the greatest possible detail - urban plans from visible surface remains in selected sites; b) propose a fine-tuned chronological attribution of sites through systematic collections of surface materials (which also define the functional interpretation of urban sectors); c) map the landscape of silted channels and possible ancient agricultural fields in extra- and intrasite areas; d) integrate epigraphic sources and surface evidence from settlement patterns into reconstructions of historical geography.

This research design is applied to the study of multilayered landscapes in central-southern Iraq with the aim of shedding light on the formation of urban centers. One of the main objectives of the survey project is that of understanding the relation between the spatial clustering of human communities and the organization of irrigated agriculture, which appear to be the main variables in the southern Mesopotamian eco-social system during much of its history.

Several crucial questions still necessitate to be tackled. A fundamental as well as thorny issue is that of the ceramic indicators, which were very sketchily described by previous survey projects (Adams 1981; Adams/Nissen 1972; Gibson 1972). Nowadays they still present a degree of uncertainty for some of the periods considered, such as the Late Chalcolithic 1-3 phases, the transition from the 2nd to the 1st millennium BCE, the Achaemenid period, the distinction between the Seleucid and Parthian assemblages but quite often also between Parthian and Sasanian sherds. We have relied on the published excavated sequences for central and southern Mesopotamia (rather than the Diyala sites), such as Tell el-Oueili, Uruk, Jemdet Nasr, Nippur, Abu Salabikh, Fara, Larsa, Tell al-Wilaya, Tell ed-Der, Babylon, Seleucia and Nishapur (Armstrong/ Gasche 2014; Cellerino 2004; Huot 2003; Hussein et al. 2009; Matthews 1992; McCown et al. 1978; McMahon 2006; Moon 1987; Zettler 1993; Rante/Collinet 2013). As for the archaeological periodization, we sticked to the historically-based prevailing one, although we remain unconvinced by it since a more neutral one such as the one based on technological eras (Chalcolithic, Bronze and Iron) would be more advisable in general. 


\subsection{The survey area and previous researches therein (NM)}

The QADIS survey area provides a perfect environment for reinvestigating the historical trajectories of southern Mesopotamia from prehistory to the Ottoman period. The main criteria, based on classic (Adams 1981; Adams/ Nissen 1972) and new research perspectives (Hritz 2010; Wilkinson et al. 2013; Ur 2013a), for the selection of the area to be investigated have been:

1) Ample available data about settlements and waterways distributed across the entire chronological range of the region.

2) The widest range of site size for each chronological phase.

3) Evidence from new unrecorded sites to integrate into the existing dataset.

4) A wide range of sites of different sizes and from different periods, with visible structures.

The survey area (Fig. 2; $1829 \mathrm{~km}^{2}$ ) follows the administrative borders of the region of Qadisiyah to the south and east (including part of the Delmej basin); to the west it lies north of the line connecting Isin and Shuruppak; to the north it ends at the town of Afak. No recent or ongoing projects were active in this region during our three years of fieldwork, the major sites of Nippur and Umma and their immediate catchments lying outside of our surveyed area.

Previous surface surveys in the QADIS area (Table 1) were carried out at Fara and its environs in 1902-1903 (Andrae 1903) and again in 1973 (Martin 1983; 1988), in 1925-1926 and in 1968 in an area larger than ours (Dougherty 1926; Al-Shukri 1974). Between 1968 and 1975, Adams carried out surveys in the area (Adams 1981; Adams/Nissen 1972). Tell Dlehim was briefly explored in 1988 (Anonymous 1989). As regards excavations, Abu Hatab was briefly investigated in 1902-1903 (Andrae 1903; Heinrich/Andrae 1931, 137). Adab was extensively excavated between 1903 and 1905 (Wilson 2012), while in 1977 a single season was carried out at Umm al-Hafriyat (Gibson 1977/78), which unfortunately is still basically unpublished. After both the Second and Third Gulf Wars, under extremely difficult conditions for the management and preservation of archaeological heritage (see especially Emberling/Hanson 2008 and Stone 2008 on the looting peak between 2003 and 2007), the State Board of Antiquities and Heritage (SBAH) carried out several regular or emergency excavations at the sites of Tell Dhuhaia, Bismaya/Adab (Al-Doori et al. 2001-2002), Tell Mirza, Tell Ruejeh and Tell Delmej 1-2 in the Delmej Basin, Tell al-Akhader, Tell Abu Edan, Tell el-'Arris and Tell Drehem/
Puzrish-Dagan (Al-Mutawalli/Shalkham 2014; Al-Mutawalli et al. 2017) (Table 2).

\subsection{The field activities of the 2016-2018 survey campaigns (FZ)}

The main activities carried out during the six survey campaigns from 2016 to 2018 (Al-Hussainy/Notizia 2018; Al-Hussainy/Notizia in press; Marchetti et al. 2017a; 2017b; Marchetti 2018; Marchetti et al. 2018) included:

1) Settlement pattern analysis. Analysis of satellite imagery and ground truth verification in the field of anomalies identified as potential archaeological sites. In total, we identified 208 anomalies through remote sensing, 146 of which were confirmed by ground truthing to be mounds corresponding to 120 single or multi-period archaeological sites. In total, the QADIS project increased the number of known sites in the area by about $28 \%$ (415 from Adams' "Heartland of Cities" survey and 120 from the QADIS survey project). We have labeled all of the new sites surveyed by the QADIS project with the prefix "QD" followed by a progressive number (001, 002, 003 etc.). Our distinction between mound and sites differs from Adams' methodology, who labeled instead each mound with a progressive number (Adams 1981, Adams/Nissen 1972). This system affected the understanding of coeval neighboring sites possibly forming a common urban environment (e.g. Tell Drehem, which is made by Adams' sites nos. 1000, 1001; Adab and Adams' site No. 1426; Tell el-Laham, Adams nos. 1230, 1231, 1233) or groups of neighboring mounds of different periods that may actually be the result of a shifting of the location of the same site over time (e.g. QD008a-d corresponding to Adams nos. 1090 and 1091, QD105a-c corresponding to Adams nos. 25 and 26). The QADIS project considers these two types of evidence as single archaeological sites and accordingly labels them e.g. QD075a, QD075b etc.

2) Analysis of the paleochannel systems. Analysis of satellite imagery and ground truthing of paleochannels in the field. We first carried out landscape analysis on the basis of previous (Adams 1981; Wilkinson 2003) identifications of paleochannels and then integrated or corrected them with the help of satellite imagery (Corona, SRTM, Landsat, Bing Maps Tile System; see Table 3) and in a few cases also with orthophotos taken by drones. As a result, if on the one hand we found that paleochannels previously identified were sometimes no longer visible, on the other hand we 
managed to detect new paleochannels (almost 700 so far). This situation can be explained in the light of the growth of intensive agriculture in the area since the 1960 s. Additionally, we have been conducting geoarchaeological investigations since 2017 to test the chronology of the paleochannels and detect potential harbors.

3) Analysis of urban evolution through time. We carried out an intensive survey of ten sites showing visible structural evidence in satellite imagery. The survey consisted of orthophotogrammetric mapping using $\mathrm{UAV}$, followed by intensive material collection (see below) to confirm chronological attribution and function (Table 4).

\section{Methodology}

We describe here the workflow methodology applied for the QADIS survey project from pre-field activities to post-processing. In designing the survey project, we attempted to address different issues possibly affecting the research methodology and results including the availability of the state-of-the-art information (base maps for pre-field activities), the different terrain condition of the region (affecting visibility or the capacity of the personnel to detect materials in the field) or the ability of classifying archaeological materials in a correct manner (Banning 2002; Banning et al. 2017). In the following paragraph we discuss the project workflow from the pre-field activities (4.1) to the different types of research carried out in the field (4.2 to 4.5).

\subsection{Creating the base maps (MV - FZ)}

Over the last two decades, archaeologists working on early Mesopotamia developed new approaches to the exploration of cultural ecology by means of remote sensing at the top of their agendas (Cole et al. 1998; Hritz 2010; Pournelle 2003; Wilkinson et al. 2013;, 2015). The use within GIS software of different spatial datasets - including historical and currently available satellite imagery (World View, Geo-eye, Landsat, SRTM and Corona among others), often available through open-access online platforms (Google Earth Pro, Bing Maps, USGS, CAST; Table 3) - in combination with past archaeological surveys has been broadly recognized as crucial for archaeological investigations at any scale (Hritz 2010, 189f.; Pournelle 2003; Ur 2006; Ur 2013a; Wilkinson 2003). Attempts to apply this method have been made in Mesopotamia since the late $1990 \mathrm{~s}$, both at regional (Cole et al. 1998; Hritz 2004; 2010; 2014; Hritz/Wilkinson 2006; Jotheri et al. 2016; Pournelle 2003; 2007; Stone 2008; 2013) and intra-site level (Stone/Zimansky 2004).

As to the QADIS project, we started from the previous surveys (Adams/Nissen 1972; Adams 1981; Al-Shukri 1974), carried out in our survey area. We first georeferenced Adams' maps in UTM 38S Zone with a GIS software, using the georeferenced points on the maps and the most easily recognizable features (e. g., river junctions) as reference points, and then integrated this data with Landsat, declassified Corona and several sets of satellite imagery provided by the Bing Maps Tile System in order to make sure our data were as up-to-date and accurate as possible. We first positioned the sites on the newly georeferenced maps by Adams, then corrected any shifts in site location ( $1 \mathrm{~km}$ at the maximum) by using photo-interpretation of satellite imagery. We also incorporated 1:50,000 and 1:100,000 topographic maps, and a mosaic of ESRIC high-resolution satellite images provided by the Iraqi SBAH (Fig. 3). This step also allowed us to obtain a digital base map, which we used as a starting point for the identification of archaeological sites and paleochannels.

We managed to detect several sites or groups of sites where Adams' map $(1981,364)$ showed a confluence of lines, tentatively interpreted as paleochannels.

The criteria applied to select the different sets of satellite imagery composing the basemap include: 1 . accessibility (open-access), 2. multi-temporality and multi-seasonality. Criteria no. 1 is especially crucial, because verifiability, comparability and alternative testing by peers must be grounded on similar sets of evidence. The open-access Bing Maps Tile System (and the ESRIC satellite imagery provided by the SBAH) enabled us during the remote sensing stage not only to rectify the position of Adams' sites but also to detect new archaeological sites and paleochannels (Stone 2008; 2013). Many of these paleochannels had not been previously identified by Adams, which of course cannot be relatively modern because of their lack of clear-cut rectilinear features and because some of them are also visible on the Corona. Another 60 anomalies (i. e. ground discoloration, irregular rounded patterns, or other discontinuities visible in remote sensing) provided no archaeological evidence when verified on the ground, since they did not yield surface materials at all; these were registered as "No-Site" and their limits drawn by taking handheld GPS points so that future remote sensing investigations will not misidentify them as sites again.

Over the last ten years, Landsat satellite imagery has become increasingly important for archaeological 
research (Ur 2006; Kennedy/Bishop 2011). In the case of the Qadisiyah region, the archive of layered Landsat imagery freely available through the USGS website consists of 32 photos taken between 1984 and 2016. Landsat image resolution has increased through time; more specifically, thanks to the Thematic Mapper ${ }^{\mathrm{TM}}$ sensor used since Landsat 4 and Landsat 5 , the ground resolution has increased from $60 \mathrm{~m}$ to $30 \mathrm{~m}$. Therefore, while the majority of earlier images, due to their lower resolution, are mostly used for preliminary identification of macro-anomalies some of the latest Landsat images allow for the identification of intra-site anomalies.

Corona satellite images, the use of which has rapidly spread among archaeologists over the last two decades (Casana/Cothren 2008; Hritz 2010; Pournelle 2003; Ur 2013a), have also been a valuable tool for geo-rectification and site detection. They were particularly useful in our case, since they were taken between the $1960 \mathrm{~s}$ and $1970 \mathrm{~s}$, at the same time when the American surveyors worked in the area. In addition, despite their lower resolution (2-3 m at best), Corona satellite images captured a landscape predating the major urban and agricultural transformations of the last 40 years (Hritz 2010, 189).

Shuttle Radar Topography (SRTM) has proved to be another valuable tool for detecting water channels, as well as some major sites. It has already been successfully used at the regional scale (Cole et al. 1998; Hritz/ Wilkinson 2006; Jotheri et al. 2016), allowing researchers to update the interpretations based on the "Heartland of Cities" surveys (Adams 1981).

Soviet as well as US topographic maps provided useful support in distinguishing between modern channels, roads and villages. However, as their purpose was to document modern features (Davis/Kent 2017), only a few sites are marked in them.

\subsection{Aerial photogrammetric survey and geo- referencing methods $(\mathrm{GL}-\mathrm{MV})$}

The integrated use of a variety of satellite imagery led to many new discoveries, revealing unexpected anomalies potentially identifying human-made structures or paleochannels. These necessitated validation in the field; consequently, the QADIS survey project used UAVs (Unmanned Aerial Vehicles) to produce detailed maps of the sites showing all visible structures and paleochannels. Drones have been generally employed over limited areas, to detect sites or visible structures, while at the intra-site level they provide a valuable alternative for mapping excavated areas.
For the QADIS survey project, we used DJI Phantom 3 and DJI Phantom 4 Pro drones to verify the nature of anomalies previously detected through satellite imagery. To this end, we took high-resolution photos with a $3-4 \mathrm{~cm}$ per pixel resolution from altitudes between 70 and $140 \mathrm{~m}$. Depending on altitude and on the area covered by the drones, we took hundreds to thousands of photos, which we then processed using Agisoft Photo Scan $(\mathcal{C}$ and Pix4D (C) software.

We successfully applied this integrated method to selected case studies of different sizes and different terrain morphologies (from sites of less than 10 ha to 400-ha megacities). During the 2016 and 2017 seasons, we used drones on a total of 33 days to document 11 sites (Figs. 6-7), corresponding to a total area of almost 1200 ha (Table 4). An important element to be considered when designing research methods are variations in soil color and seasonality of vegetation. So far, thanks to the multiple flight tests carried out at 4 sites (Tell Dlehim, Tell Drehem, Tell Umm al-Fugas and Tell Jidr) in different seasons, including winter (January 2016, 2017, 2018) and fall (October 2016, 2017), we were able to observe a variety of building vestiges and isolate multiple variables affecting the interpretation of ancient buildings.

\subsection{Surface collection (intensive and non- intensive surveys) (AH - GS - FZ)}

Surface collection must take into account different factors including artefact obtrusiveness, visibility and the capacity of team specialists to identify and properly document surface materials (Banning 2002; Banning et al. 2017). One typical problem of the QADIS survey project has been the chronological reliability and precision of ceramic indicators (which Adams 1981 almost did not detail).

A survey-resurvey strategy was applied at 57 sites previously documented (Adams 1981; Adams/Nissen 1972), in the attempt to also compare his chronological attributions. We relied on published ceramic evidence from the excavations around our survey area (since the researches discussed in $\S 3.2$ did not produce reliable data in this respect), especially, for the Pre-Classical periods, the sites of Jemdet Nasr, Abu Salabikh, Tell al-Wilayah, Umm al-Jir, Nippur, Isin, Larsa, Tell ed-Der, Babylon and, on a lesser scale, the Diyala (but cf. also § 1). In the QADIS final report, a publication in full of our recorded surface finds is foreseen. We designed two types of surface collection at the surveyed sites, namely intensive and non-intensive (Fig. 4a-b). Our criteria for the selection of intensive or non-intensive surface collection include visibility of 
structures at sites through remote sensing or drone flights and the degree of looting, which dramatically affect data accuracy.

We documented the great majority of sites, where we carried out surface collection, by doing a non-intensive collecting of diagnostic materials useful for reconstructing the chronology of the sites and, in some cases, of work areas (i.e. cluster of slags, flints etc.): initial investigation at each site aimed at detecting its limits (based on the presence/absence of material culture on the surface), then, starting from the centre of the site, the members of the survey team (generally 5 to 7 ) followed a radial pattern covering a transect about $2 \mathrm{~m}$ wide in which they collected diagnostic pottery (rims, bases and decorated bodies) and small finds (Fig. 4a). This allows an assessment of spatial shifts of occupation along the radial axis of sites, a telling if not overly precise information, which is balanced by its relative speed both in collecting and in processing surface materials in the documentation chain.

On the other hand, we carried out intensive surface collection at 8 medium-sized and large sites (Tell Rumah, Tell Umm al-Fugas, Bismaya/Adab, Tell el-Ahmar, Tell Dlehim/Tummal?, Tell Drehem/Puzrish-Dagan, Tell Abu Hatab/Kisurra, Tell Jidr/Karkara) showing extensive surface structural evidence including houses, large buildings, city-walls, fortresses, and hydraulic features, both inside the city limits and in the surrounding landscape. For each site, we created a three-tier topographic system comprising sectors, sub-sectors and squares. Sectors delimit large areas characterized by a common terrain morphology, while smaller morphological features within a sector, such as cultivated fields bounded by channels or smaller mounds, are designated as sub-sectors (Figs. $4 \mathrm{~b}, 5)$. Each sub-sector may include one or more squares forming grids ranging from $50 \times 50 \mathrm{~m}$ to $100 \times 100 \mathrm{~m}$, following an approach already tested elsewhere (Stone/Zimansky 2004, 44), to allow site-to-site comparisons. One or two team members worked in each square, collecting all the diagnostic pottery (rims, bases and decorated bodies) and small finds. This method entails not only the greatest precision about the development of sites through time, but it also tells us about differing functional assemblages in dense urban environments.

\subsection{Test soundings (NM)}

We conducted a few test soundings in selected areas where drone imagery and field survey revealed well-readable structural features (at Tell Umm al-Fugas, Tell Dlehim, Adab and Tell Jidr). We had already carried out intensive surface collection in these areas in order to provide preliminary dates for them. The aim of the soundings was twofold: to identify structural evidence detected through remote sensing and UAV flights, and to provide further chronological data to verify the results of intensive surface collection. In architecturally homogeneous areas, a small test sounding may yield evidence increasing the accuracy of the dating of the whole sector it lies in. However, even when structures are well visible on the surface, their preserved elevation is almost always very limited; these soundings thus often involved little more than superficial scraping. They should not be understood as random excavations, but as a complement of the survey (an approach somehow already advocated by Adams 1981, 47, although not exactly in these terms). For example, at Adab (Fig. 6) to the east of the site there is a large quarter dated to the Akkadian period by the pottery scatter and with well visible surface remains, consisting of houses along a regular grid of streets and what seems a large public compound of palatial nature. Three areas (Soundings A-C) were scraped superficially revealing structures preserved to a height of a few cms at most, but confirming both the date and the layout which was observed on the surface.

\subsection{Geoarchaeology (GS - FZ)}

We have recently extended our research method to include geoarchaeology with the aim of investigating the hydraulic landscape in the region through time. We built upon the current state-of-the-art in terms of research methodologies (Jotheri et al. 2016) and narratives (Pournelle 2003; Rost 2017; Wilkinson 2003; Wilkinson et al. 2015) to contribute to the reconstruction of the development of the ancient hydraulic landscapes through time (cf. also § 4.1).

In the two seasons of geoarchaeological investigations, we carried out 30 boreholes, located both across paleochannels noted through remote sensing and validated by ground control and areas thought to represent potential harbors within large urban sites (such as at Bismaya/Adab QD049, Tell Drehem/Puzrish-Dagan QD015 and Tell Jidr/Karkara QD013). The depths of the cores usually range between 5-6 and 14-15 m, depending on soil texture and the elevation of the water table.

Some preliminary results on the detailed reconstruction of urban hydraulic landscapes around selected major sites within specific time slices, such as at ED III Bismaya/ Adab (Fig. 6) and Ur III Tell Drehem/Puzrish-Dagan, are now available (Fig. 7): the tiny pottery fragments from the cores were carefully studied as well as the nature of the sediments sampled therein. However, for the time being, 
the dating of the majority of traced paleochannels relies upon the chronology of the sites located along them. While we are aware that this method is often error-prone, we must acknowledge that a systematic coring strategy and $14 \mathrm{C}$ dating of the regional network of paleochannels was not economically and temporally sustainable during the first, completed phase of our project.

\section{A Regional Picture of Early Meso- potamian Urbanism}

In this section, we make use of the datasets obtained via new fieldwork to provide a more thorough characterization of urban developments in the study area over the $4^{\text {th }}$ and $3^{\text {rd }}$ millennium BCE. We focus on: 1) urban scale, 2) overall population scale, 3) settlement hierarchies, 4) waterways.

The new data provided by the QADIS survey project allow to propose a more accurate analysis of the settlement dynamics in the region from the early $4^{\text {th }}$ millennium BCE to the end of the $3^{\text {rd }}$ millennium BCE. Previous narratives (Algaze 2008; Ur 2013b; Wilkinson 2003; Wilkinson, Ur/Hritz 2013) are mostly built upon the results by Adams (1981; Adams/Nissen 1972) and Wright (1981). We compared the six-level hierarchy system proposed by Adams (1981, 136-141, table 14) $)^{1}$ with other site size classifications not only based on the chronology of surface finds but also on other variables including textual data. As a result, while no agreement has been established regarding the best settlement hierarchy to be used, and since the six-level hierarchy proposed by Adams is not supported by other examples, we attempted to improve the system comparing existing literature and the new QADIS sites dataset. As pointed out by Wilkinson/Ur/Hritz (2013, quoting Steinkeller 2007), if we consider both archaeological, historical and philological sources, we may shrink Adams' six tiers system to a three-level model: urban centers (100-200 ha), towns (7-30 ha), and villages ( $2 \mathrm{ha}$ ). This proposal is supported by a further analysis based on the rank-size of southern Mesopotamian sites, which shows three macro-levels of settlement hierarchy: $0-8 / 9$ ha; $9-80 / 90$ ha; $>80 / 90$ ha (Wilkinson/Ur/Hritz 2013). We followed the three tiers system, although adapting it to the size clusters of the new sites documented by the QADIS project. In order to be able to compare these data with Adams' results

1 1. $0.1-4.0$ ha; $2.4 .1-10.0$ ha; $3.10 .1-20.0$ ha; 4. 21.1-40 ha; 5. 40.1200 ha; 6. >200 ha.
(1981), we defined the three tiers as follows: 1) 0-10 ha, 2) 10-40 ha, 3) >40 ha.

Another purpose of the QADIS survey project was that of challenging current interpretations of the demographic trends in Southern Mesopotamia. While we cannot do justice here to the debate on population estimates in the Near East (e. g., Algaze 2008; Colantoni 2017; Postgate 1994; Wilkinson 2003; Wilkinson/Ur/Hritz 2013), using the new QADIS data on site size and chronology we attempted at building on the existing narrative, with the aim of reconstructing the development of settlement strategies from the early $4^{\text {th }}$ millennium BCE to the late $3^{\text {rd }}$ millennium BCE in the region. To calculate the population estimate, we relied upon the current agreement of around 150 persons per ha (Stone 2013; Wilkinson et al. 2013). We defined rural population living in sites of the lowest tier (0-10 ha) vs urban population inhabiting the sites in the other two tiers (10-40 ha and $>40$ ha). This division is an admittedly preliminary attempt to distinguish between villages and cities/towns based on Pollock (1999) and Steinkeller (2007), both proposing \pm 7 ha as a meaningful threshold and Wilkinson et al. (2013), proposing an 8-9 ha threshold between villages and cities/towns.

\subsection{Uruk and Jemdet Nasr periods (GB-FZ)}

Post-processing of survey data has enabled us to distinguish between settlement patterns relating to the ill-documented Early and Middle Uruk phases (Fig. 8a), on the one hand, and the Late Uruk phase (Fig. 8b), on the other. In the earliest Uruk phases, all sites in the study area seem to be located along waterways. Three main water systems can be reconstructed for this phase, namely, two branches of the Tigris in the northern part of the survey area (hereafter, Tigris North and Tigris South) and the Euphrates, which borders the survey area to the south. Although most of the sites extend over only a few hectares, in this phase we were already able to single out at least five sites with areas ranging between 10 and 40 ha, namely, QD077, QD064a and QD046 along the Euphrates system, and nos. 1172 and 1194 along the southern Tigris system, where the network of sites appears to be denser (Fig. 9). During the Late Uruk period, the settlement density of the whole area apparently decreased, especially along the northern Tigris and the Euphrates watersheds (Figs. 8b). Only two urban sites, nos. 1172 and 1194, exceed 10 ha in this period (Fig. 10). These changes can perhaps be connected to the century-long period of aridity - the $5.2 \mathrm{ka}$ BP event that may have severely impacted irrigation agriculture in southern Mesopotamia (Staubwasser/Weiss 2006, Table 1, 
379). Interestingly, in the Jemdet Nasr phase (Fig. 8b), the northern Tigris system seems to become extinct in our area and a marked decrease of settlement density also characterizes the southern Tigris. Conversely, a slight increase in site density can be detected in the southern portion of the survey area, where small sites and one large urban site (QD112) seem to cluster along a dendritic network of channels, possibly connecting the Tigris and Euphrates systems in the proximity of the site of Umma.

Turning to the ratio between urban dwellers and rural population, Fig. 11 shows that during the Uruk and Jemdet Nasr periods between 70 and $90 \%$ of the total supposed population of the region was settled in sites ranging between 0 and 10 ha, which we consider as rural sites, while only up to $30 \%$ of the population was settled in urban centers of 10 to $40 \mathrm{ha}$. It is worth noting that the area under examination seems to reach a peak of settled surface in the Early-Middle Uruk phase, but then the data show a marked decrease of total settled area that corresponds to the Late Uruk period, a phase traditionally deemed to be the apex of early southern Mesopotamian urbanization (but cf. Ur 2013b, fig. 7.9 and his comments on the intraregional shifts, within which the developments in our survey area must be framed too).

The fresh dataset regarding the relationship between settlements and waterways in the region tallies with previous hypotheses stemming from geoarchaeological investigations conducted in the area (Wilkinson et al. 2015). According to these hypotheses, a levee-based system consisting of central longitudinal waterways and spur channels (cf. Wilkinson et al. 2015, figs. 3, 7) was already developing during the $4^{\text {th }}$ millennium BCE in the area between Nippur and Adab. If so, gravitational irrigation and extensive cropping on levee slopes were feasible, perhaps by exploiting the crevasse splay method (Rost 2017, 8; Wilkinson et al. 2015, fig. 6).

\subsection{The Early Dynastic period (GB-FZ)}

Settlement patterns of the early Early Dynastic phases (Fig. 8c-d) in the study region indicate significant urban density, with a growth of small-scale settlements connected to the Tigris and the Euphrates systems (Fig. 9), but also with remarkable clusters in the area between the two, as well as a significant growth of urban enclaves (Fig. 10). Nippur, Umma and Shuruppak are the among the main urban sites of the phase, but several large sites can be also distinguished in the QADIS area (QD017, 1421, Adab, QD141, Karkara, QD112, QD026, QD064a). One of these already exceeds 40 ha of size (QD141), suggesting a tripartite settlement hierarchy at the beginning of the Early Dynastic period.

The onset of the Early Dynastic period (Fig. 8c) can be characterized as a turning point for the relationship between urban and rural settlement. As shown in Fig. 11, during the ED I and II periods the total projected rural and urban population seems aligned, with the population almost equally split between urban sites of more than 10 ha and rural sites of less than 10 ha. This phenomenon can be possibly understood as the proper urban takeoff in the area under examination. An increase in total settled area is registered also for the areas of Nippur and Uruk and Ur and Eridu (Ur 2013b, fig. 7.9) in this phase.

The subsequent period (Early Dynastic III) is characterized by a marked decrease in the number of small sites (Fig. 8d), counterbalanced by significant increase in the size of major urban sites, with Nippur, Adab, Umma and Shuruppak now well above 40 ha in extension. The site of Adab (Fig. 6) is the behemoth of our survey area during the $3^{\text {rd }}$ millennium BCE, with its 240 hectares. Notwithstanding very heavy looting on the main mound, several urban features were revealed by surface surveys: the city has a walled main central sector (extending for 56 hectares) encompassed on all sides by waterways, a branch of the Tigris along its West side and canals on the others. A harbor, as revealed by boreholes, was also present at least since ED I. To the South another seemingly walled quarter encloses the temple area excavated by Banks as well as looted residential quarters which gave pottery assemblages dating mainly from ED II (which is a phase which can actually be recognized in the material record). To the West of the Tigris there was an industrial area as the slags on the surface suggest, while for the Akkadian settlement to the East, see above $\S 4.4$.

According to our estimates (Fig. 11), the total urban population for this phase in the QADIS area reaches a peak of ca. 60 to $90 \%$, while rural dwellers seem to make up between 10 and $40 \%$ of the total inhabitants. In this case, the pattern reconstructed by Adams and his followers seems to be confirmed (cf. Ur 2013b, fig. 7.9). In the region belonging to outlying Umma, besides the main urban centers mentioned above, sites Adams nos. 175 and 190 become large urban entities, while further North, along the Tigris, we encounter Karkara, QD120, Adab, and Umm al-Hafriyat.

There is agreement among scholars that the main rivers in the southern Mesopotamian plains took braided patterns in the Early Dynastic period as a consequence of the formalization of artificial irrigation systems consisting of spur canals and water-control devices (Rost 2017, 9; Steinkeller 2001; Carroué 1991; 1993). This appears to 
be confirmed by the fact that small sites in the latter Early Dynastic period appear to be evenly distributed across the countryside, apparently connected by a dendritic network of secondary channels crisscrossing the plain between the courses of the Tigris and Euphrates.

\subsection{Akkad to Ur III periods (GB)}

The most significant change in the settlement patterns of the Akkadian period was the dramatic decrease of sites connected to the Euphrates branch flowing to the south of Nippur, which is part of an overall decrease in the total settled area for the study region (Fig. 8e). The area between Shuruppak and Umma in particular, was almost completely abandoned. Sites now mostly cluster along major waterways and in particular along the Tigris South branch (Fig. 9). Urban sites of regional importance seem to include Nippur, Adab and Umma, all extending in this phase over more than 40 ha. Then comes a number of second-tier settlements, some of which are already attested in the previous periods (Fig. 10), such as Karkara, 175, 190 and Umm al-Hafriyat/Mashkan-ili-Akkade (Milano/Westenholz 2015), QD020a, QD017, site 1115.

The ratio between urban and rural population in this phase (Fig. 11) indicates a new increase in the total rural population, resulting in a more even distribution of people between urban sites (50-70\%) and villages (20-40\%). However, urban sites in this phase do not exceed 40 ha. Altogether, the decrease in settlement density and the clustering of sites along major waterways seem to indicate a virtual abandonment of the dense network of subsidiary channels crisscrossing the floodplain attested in the former phase. This datum is in line with the changes connected to a major climatic shift towards drier conditions - the $4.2 \mathrm{ka}$ BP event - that reduced water availability for the Mesopotamian plains from ca 2250 BCE and had a strong impact on the communities located along the Tigris and Euphrates watersheds (Cookson et al. 2019; Rost 2017, 12; Weiss 2017).

In the subsequent phase, the Ur III period (Fig. 8f), the settlement patterns reconstructed indicate a dramatic change in the landscape of the region (Fig. 9; cf. also Ur 2013, fig. 7.9). First, the overall number of sites increases sharply. Second, a three-tier hierarchy, with sites ranging between 0 and 10 ha, urban sites between 10 and 40 ha and major urban sites exceeding $40 \mathrm{ha}$, can be figured out (Fig. 10). Third, both the urban and the rural population increase, with the former between ca. 60 and $80 \%$ and the latter between ca. 20 and $40 \%$, evenly distributed in the plain (Fig. 11).
The major settlements of the area were certainly the newly-founded management center of Puzrish-Dagan, Tummal, Kisurra and Karkara, plus outside this area the centers of Nippur and Umma (Steinkeller 2001). Puzrish-Dagan/Tell Drehem extends for 60 hectares (Fig. 7) and, like Adab, is surrounded on all sides by canals (that also a central one has been there seems doubtful at present). City walls could be observed only to the SouthEast of the temple compound, which seems to have consisted of a broad room cella opening onto a courtyard and lying against a mudbrick terrace (rather than a proper ziqqurat). The urban grid is quite regular and it is clear that large administrative buildings, such as the one excavated by Shalkham (Al-Mutawalli et al. 2014; 2017) were distributed all over the site. A harbor once again confirms the importance of water transportation for Mesopotamian cities.

Compared to the former phase, when most of the settlements clustered along the Tigris, in the Ur III period the branch of the Euphrates flowing through the region regains its importance. As to waterways, the distribution of small and medium-sized settlements in the floodplain indicates that a dendritic system of spur canals was fully re-established by this phase. Royal inscriptions inform us that the Ur III kings were particularly active in the area, digging a major canal connecting the Euphrates and the Tigris between Kisurra, Adab and Karkara (Rost 2017, 12; Frayne 1997, 241 f., Map 1). These sites became administrative centers controlling the economy of the surrounding hinterland, which was divided into districts (Steinkeller 1991). The political core of the region was the area to the south of Nippur, where major construction projects were carried out by the central government (Steinkeller 2015). Puzrish-Dagan became the main collection and distribution center for livestock in connection with state taxation, and the seat of important branches of the government (Steinkeller 1991, 24; Tsouparopoulou 2013; Al-Mutawalli et al. 2017), while at Tummal a large royal palace was built by Shulgi and significant state cultic activities took place (Steinkeller 2015, 143. 156f.). The other political center within the survey area lay in the province of Umma and encompasses circa 50 secondary settlements. Umma probably controlled much of the southern sector of the survey area, approximately up to site no. $1459,{ }^{2}$ according to the reconstruction by Adams $(2006,136)$.

2 Called “Dibbin” by W. Andrae (Adams 1981: 286). 


\section{Conclusions}

The activities of the QADIS project are built upon two different, but interrelated, methodological strands: one to be adopted in the field and the other for the processing of fieldwork data. This allowed us to produce a series of time-maps detailing the development of urban, rural and natural landscapes in the study area in the $4^{\text {th }}$ and the $3^{\text {rd }}$ millennium BCE. The new maps allowed us to provide some interesting new insights on regional trajectories of the evolution of urban societies in southern Mesopotamia (Fig. 12).

It is becoming increasingly evident that the early Mesopotamian urban phenomenon, which previous studies tended to make homogeneous and similarly paced, is characterized by sharp differences in terms of regional dynamics, urban shape (low vs. high-density) and impact on the natural environment. The finds from the QADIS project indicate general patterns that are in line with the development trajectories reconstructed by Adams for the Nippur and Uruk regions, but markedly different from the ones traced for the area of Ur-Eridu, the Diyala region, and, of course, the northern Mesopotamian zones (in the modern state of Syria and in Iraqi Kurdistan). The region subjected to fieldwork, in particular, demonstrates that much more work on the early $4^{\text {th }}$ millennium BCE (Early-Middle Uruk) is required to better understand the inception of the "Uruk phenomenon", the latter part of which appears to be, on the basis of old and fresh datasets, a phase of decline in the amount of both urban and rural sites probably to be connected to a worsening of climatic conditions. In the same vein, another turning point for early southern Mesopotamian urbanism seems to be represented by the onset of the $3^{\text {rd }}$ millennium BCE (or ED I), a phase which is still ill-characterized in terms of social and political developments, but that displays in both the QADIS survey area, and in the Ur-Eridu enclave, the characters of a proper urban take-off. The ED II-III periods see a concentration with a decrease of the number of settlements vs larger urban sites. During the Akkadian period more specialized, smaller sites or even quarters seem to have been there, a trend greatly expanded during the Ur III phase when the canal network seems to have been extended as well. Altogether, these findings highlight that, to better understand a complex phenomenon such as that of Mesopotamian urban formation, the contribution of regional surveys that apply integrated archaeological methodologies targeting both urban and subsistence landscapes is crucial.
Acknowledgements: The friendly and unfailing cooperation of the then Chairman Qais H. Rasheed and of all the colleagues at the State Board of Antiquities and Heritage in Baghdad is here gratefully acknowledged. The QADIS project is directed by N. Marchetti. Funding for the six survey seasons (carried out each January and October between 2016 and 2018) was provided by the Alma Mater Studiorum - University of Bologna, the Italian Ministry of Foreign Affairs (DGPS Directorate $-6^{\text {th }}$ Office) and the European Horizon 2020 JPI CH Project "HeAT" coordinated by N. Marchetti. The Ludwig-Maximilians-Universität München (LMU Munich) contributed to the second and third seasons. This article has been produced with the assistance of the European Union in the frame of the EU-funded project "EDUU - Educational and Cultural Heritage Enhancement for Social Cohesion in Iraq" (EuropeAid CSO-LA/2016/382-631), coordinated by N. Marchetti. The contents of this article are the sole responsibility of the authors and can in no way be taken to reflect the views of the European Union. We are very grateful to the diplomatic personnel of the Italian Embassy in Baghdad and the local Authorities and the many friends in Diwaniyah and Afak for their warm reception and constant support. In addition to the authors, the following colleagues took part in the first six seasons of the QADIS survey: Nadia Barbi, Michael Campeggi, Claudia D’Orazio, Berthold Einwag, Valentina Gallerani, Gabriele Giacosa, Christoph Fink, Elena Leoni, Hardy Maaß, Eleonora Mariani, Jacopo Monastero, Adelheid Otto, Giulia Roberto, Hayder La'ebi, Ahmed Kareem, Ahmed Abbas, Jacob Jawdat, Basim Jabbar, Ahmed Ali Jasim, Ali Feles, Mutaz Sami Rhman, Walid A. Yusif, Ghassan Adnan, Mohammed M. Dahash, Ahmed Salah, Haneen Taher, and Munna Maki. Simone Mantellini took care of drilling and studying the boreholes, samples of which were discussed together with Vincenzo Picotti (ETH, Zurich). During the first three seasons, the QADIS survey area also included the region of Fara/Shuruppak and the work carried out there has been preliminarily reported by Marchetti et al. 2017; however, since that sector (measuring $628 \mathrm{~km}^{2}$ ) subsequently became the focus of a separate project led by A. Otto on behalf of the LMU (Otto et al. 2018), it has not been included in the present paper. Google Earth Pro, Bing Maps, ESRI and Agisoft Photo Scan are registered trademarks. The U.S. topographic maps were kindly provided by E. Leoni (University of Bologna). The 1:50,000 topographic maps were taken from Series K743, 2006-2010, while the 1:100,000 topographic maps were taken from 1976 100K mapping, Sheets I-38-139, I-38-140, H-38-7, H-38-8. The 1:200,000 Soviet topographic military maps 1990-1991 are freely available (for other study cases in the 
Near East employing these maps, see Bitelli et al. 2013). Further support was also provided - in visualization-only mode - by TomTom $\subset$ and Garmin ${ }^{\circledR}$ GPS satellite photos, which provided higher-quality images for several portions of the survey area. Finally, while this essay is a truly collaborative effort of the authors, individual paragraphs have been credited by their initials.

\section{References}

Adams, R. McC. (1965): Land behind Baghdad. A history of settlements in the Diyala plains. Chicago

- (1966): The Evolution of urban society. Early Mesopotamia and Prehispanic Mexico. Chicago

- (1981): Heartland of cities. Surveys of ancient settlement and land use on the central floodplain of the Euphrates. Chicago

- (2006): Shepherds at Umma in the Third Dynasty of Ur. Interlocutors with a world beyond the scribal field, Journal of the Economic and Social History of the Orient 49, 133-169

Adams, R. McC./H. J. Nissen (1972): The Uruk countryside. The natural setting of urban societies. Chicago

Algaze, G. (1993): The Uruk world system. The dynamics of expansion of early Mesopotamian civilization. Chicago/London

- (2008): Ancient Mesopotamia at the dawn of civilization. The evolution of an urban landscape. Chicago

Al-Doori, R./R. Al-Qaisi/S. Al-Sarraf/A. Al-Zubaidi (2001-2002): The final report of the Basmaia excavations (first season), Sumer 51, 58-72

Al-Hussainy, A./P. Notizia (2018): New epigraphic materials from Tell Drehem/Puzriš Dagan: the stamped bricks of Amar-Zuena, Orientalia 87, 38-55

- (forthcoming): Another stamped brick of Amar-Zuena from Tell Drēhim (ancient Puzriš-Dagān), Ash-sharq

Al-Mutawalli, N./A. U. Shalkham (2014): From the archive of "DI. KU-mīsar”. Excavation of Drehem (ancient Puzriš-dDagān), Sumer $61,19-40$

Al-Mutawalli, N./W. Sallaberger/A. U. Shalkham (2017): The cuneiform documents from the Iraqi excavation at Drehem, Zeitschrift für Assyriologie und Vorderasiatische Archäologie 107, 151-217

Al-Quntar, S. (2016): Craft specialisation and the process of urban growth in Northern Mesopotamia in the Late Chalcolithic. A view from the Syrian Jazira, in M. Iamoni (ed.) (2016b), 159-182

Al-Quntar, S./A.K. Abu Jayyab (2014): The political economy of the Upper Khabur in the Late Chalcolithic 1-2: Ceramic mass-production, standardization and specialization, in A. McMahon/H. Crawford (eds.) Preludes to Urbanism. The Late Chalcolithic of Mesopotamia, Cambridge, 89-108

Al-Quntar, S./L. Khalidi/J. Ur (2012): Proto-urbanism in the late 5th millennium BC. Survey and excavations at Khirbat al-Fakhar (Hamoukar), Northeast Syria, Paléorient 37, 151-175

Al-Shukri, S. J. (1974): Archaeological survey in the region of Afak area, Sumer 30, 297-309

Altaweel, M./A. Palmisano (2019): Urban and transport scaling. Northern Mesopotamia in the Late Chalcolithic and Bronze Age. Journal of archaeological method and theory 26, 1-24

Andrae, W. (1903): Ausgrabungen in Fara und Abu Hatab, Mitteilungen der Deutschen Orient-Gesellschaft 17, 4-35

Anonymous (1989): Dlihim, Iraq 51, 254-255
Arcaute, E./E. Hatna/P. Ferguson/H. Youn/A. Johansson/M. Batty (2015): Constructing cities, deconstructing scaling laws, Journal of the Royal Society interface 12, 1-8

Armstrong, J. A./H. Gasche (2014): Mesopotamian pottery. A guide to the Babylonian tradition in the second millennium BC. MHEM 6. Ghent/Chicago

Banning, E. B. (2002): Archaeological survey. New York

Banning, E. B./A. Hawkins/S. T. Steward/P. Hitchings/S. Edwards. (2017): Quality assurance in archaeological survey. Journal of archaeological method and theory 24, 466-488

Banks, E. J. (1912): Bismya, or the lost city of Adab. New York

Bettencourt, L. M. A./J. Lobo/D. Helbing/C. Kühnert/G. B. West (2007): Growth, innovation, scaling, and the pace of life in cities, Proceedings of the National Academy of Sciences of the United States of America 104, 7301-7306

Bitelli, G./E. Mandanici/S. Mantellini/N. Marchetti/L. Vittuari. (2013): Remote sensing as an essential tool for a multidisciplinary project in archaeology. The case of the Ebla Chora Project, in: R. Lasaponaraet al. (eds.), Earth observation. A window on the past. Hannover, 3-12

Brooks, N. (2006): Cultural responses to aridity in the Middle Holocene and increased social complexity, Quaternary International 151, 29-49

Butterlin, P. (2018): Les bâtisseurs de mémoire en Mésopotamie (7000-3000 av. J.-C.). Paris

Carroué, F. (1991): Études de géographie et de topographie sumériennes II: A la recherche de l'Euphrate au IIIe millénaire, Acta Sumerologica 13, 111-156

- (1993): Études de géographie et de topographie sumériennes III: L'Iturungal et le sud sumérien, Acta Sumerologica 15, 11-69

Casana, J./J. Cothren (2008): Stereo analysis, DEM extraction and orthorectification of Corona Satellite imagery. Archaeological application for the Near East, Antiquity 82, 732-749

Cellerino, A. (2004): La ceramica dal sondaggio di Shu-Anna a Babilonia, Mesopotamia 39, 93-168

Colantoni, C. (2017): Are we any closer to establishing how many Sumerians per hectare? Recent approaches to understanding the spatial dynamics of populations in ancient Mesopotamian cities, in: Y. Heffron et al. (ed.), At the dawn of history. Ancient Near Eastern studies in honour of J. N. Postgate. Winona Lake, Vol. 1, 95-119

Cole, S. H./H. Gasche/K. Verhoeven (1998): Second and first millennium BC rivers in Northern Babylonia, in: H. Gasche/M. Tanret (eds.), Changing watercourses in Babylonia. Towards a reconstruction of the ancient environment in Lower Mesopotamia, Vol. 1. Ghent/Chicago, 1-64

Cookson, E./D. Hill/D. Lawrence (2019): Impacts of long term climate change during the collapse of the Akkadian empire, Journal of Archaeological Science 106, 1-19 
Davis, J./A. J. Kent (2017): The Red Atlas. How the Soviet Union secretly mapped the world. Chicago

Dougherty, R. P. (1926): Searching for ancient remains in lower Iraq. Report on an archaeological survey made in Southern Babylonia during the first quarter of 1926, Annual of the American School of Oriental Research 7, 1-93

Emberling, G./K. Hanson (2008): Catastrophe! The looting and destruction of Iraq's past. Oriental Institute Museum Publication 28. Chicago

Frayne, D.R. (1997): Ur III period: 2012-2004 BC. Royal inscriptions of Mesopotamia, early periods $3 / 2$. Toronto

Gibson, McG. (1972): The city and area of Kish. Miami

- (1977-1978): Nippur Regional Project: Umm al-Hafriyat, The Oriental Institute Annual Report 1977/1978, 20-26

Heinrich, E./W. Andrae (1931): Fara. Ergebnisse der Ausgrabungen der Deutschen Orient-Gesellschaft in Fara und Abu Hatab 1902/03. Berlin

Hritz, C. (2004): The hidden landscape of Southern Mesopotamia, Akkadica 125, 93-106

- (2010): Tracing settlement pattern and channel systems in Southern Mesopotamia using remote sensing, Journal of Field Archaeology 35, 184-203

- (2014): Contribution of GIS and satellite-based remote sensing to landscape archaeology in the Middle East, Journal of Archaeological Research 22, 229-276

Hritz, C./T. J. Wilkinson (2006): Using shuttle radar topography to map ancient water channels, Antiquity 80, 415-424

Huot, J. (2003): Larsa, travaux de 1987 et 1989. Paris

Hussein, S. Y./M. Altaweel/Z. Rejeb (2009): Report on excavations at Tell al-Wilaya, Iraq. Further information on the 1999 and 2000 seasons, Akkadica 130, 113-166

lamoni, M. (2016a): Larger site, better life? Site dimensions and the path to socio-economic complexity in Upper Mesopotamia across the Halaf and Ubaid period, in: Iamoni (ed.), 57-84

- (ed.) (2016b): Trajectories of complexity. Socio-economic dynamics in Upper Mesopotamia in the Neolithic and Chalcolithic period. Studia Chaburensia 6. Wiesbaden

Jotheri, J./M. B. Allen/T. J. Wilkinson (2016): Holocene avulsion of the Euphrates river in the Najaf area of western Mesopotamia. Impacts on human settlement patterns, Geoarchaeology 31, 175-193

Kennedy, D./M. C. Bishop (2011): Google Earth and the archaeology of Saudi Arabia. A case study from the Jeddah area, Journal of Archaeological Science 38, 1284-1293

Kintigh, K. W./J. H. Altschul/M. C. Beaudry/R. D. Drennan/A. P. Kinzig/T. A. Kohler/W. F. Limp/H. D. G. Maschner/W. K. Michener/T. R. Pauketat/P. Peregrine/J. A. Sabloff/T. J. Wilkinson/H. T. Wright/M. A. Zeder (2014): Grand challenges for archaeology, American Antiquity 79, 5-24

Kopanias, K./J. MacGinnis (eds.) (2016): The archaeology of the Kurdistan region of Iraq and adjacent regions. Oxford

Lawrence, D./T. J. Wilkinson (2015): Hubs and upstarts. Pathways to urbanism in the northern Fertile Crescent, Antiquity 89 , 328-44

Lawrence, D./G. J. Philip/H. Hunt/L. Snape-Kennedy/T. J. Wilkinson (2016): Long term population, city size and climate trends in the Fertile Crescent. A first approximation, PLoS One 11, 1-16

Marchetti, N. (2018): Wandering through early urbanized landscapes in Syro-Mesopotamia, in: N. Marchetti/D. Domenici (eds.), Urbanized landscapes in early Syro-Mesopotamia and Prehispanic Mesoamerica. Papers of a cross-cultural seminar held in honor of Robert McCormick Adams. Wiesbaden, 145-168

Marchetti, N./I. Angelini/G. Artioli/G. Benati/G. Bitelli/A. Curci/G. Marfia/M. Roccetti (2017a): NEARCHOS Networked Archaeological Open Science: Advances in archaeology through field analytics and scientific community sharing, Journal of Archaeological Research 26, 1-26

Marchetti, N./B. Einwag/A. al-Hussainy/E. Leoni/G. Luglio/G. Marchesi/A. Otto/G. Scazzosi/M. Valeri/F. Zaina (2017b): QADIS. The 2016 Iraqi-Italian survey season in the south-eastern region of Qadisiyah, Sumer 63, 63-92

Marchetti, N./A. Al-Hussainy/M. Valeri/F. Zaina (2018): Assessing endangered cultural heritage in central Iraq. Methods and perspectives of the QADIS survey project, Sumer 64, 11-34

Martin, H.P. (1983): Settlement patterns at Shuruppak, Iraq 45, 24-31

- (1988): Fara. A reconstruction of the ancient Mesopotamian city of Shuruppak. Birmingham

Matthews, R. (1992): Defining the style of the period: Jemdet Nasr 1926-1928, Iraq 54, 1-34

McMahon, A. (2006): Nippur V: The Early Dynastic to Akkadian transition, the Area WF Sounding at Nippur. Oriental Institute Publication 129. Chicago

McCown, D. E./ R. C. Haines/ R. D. Biggs (1978): Nippur II: The North Temple and Sounding E. Excavations of the Joint Expedition to Nippur of the American School of Oriental Research and the Oriental Institute of the University of Chicago. Oriental Institute Publication 97. Chicago

Minc, L. D./G. Emberling (2016): Trade and interaction during the era of the Uruk expansion. Recent insights from archaeometric analyses, Journal of Archaeological Science Reports 7, 793-797

Milano, L./A. Westenholz (2015): The "Šuilisu archive" and other Sargonic texts in Akkadian. Cornell University studies in assyriology and sumerology 27. Bethesda

Moon, J. (1987): Abu Salabikh excavations volume 3: Catalogue of Early Dynastic pottery. London

Morandi Bonacossi, D./M. Iamoni (2015): Landscape and settlement in the Eastern Upper Iraqi Tigris and Navkur plains (Northern Kurdistan Region, Iraq). The Land of Nineveh Archaeological Project, Seasons 2012-2013, Iraq 77, 9-40

Nissen, H. J. (1988): The early history of the ancient Near East, 9000-2000 B.C. Chicago/London

Ortman, S.G./A.H.F. Cabaniss/J.O. Sturm/L.M.A. Bettencourt (2014): The pre-history of urban scaling, PLoS One 9, 1-10

Ortman, S.G./K.E. Davis/J. Lobo/M.E. Smith/L.M.A Bettencourt/A. Trumbo (2016): Settlement scaling and economic change in the central Andes, Journal of Archaeological Science 73, 94-106

Ortman, S.G./G.D. Coffey (2017): Settlement scaling in middle-range societies, American Antiquity $82,662-82$

Otto, A./B. Einwag/A. al-Hussainy/J. Jawdat/C. Fink/H. Maaß (2018): Destruction and Looting of Archaeological Sites between Fāra/ Surrupak and Isān Bahrīyāt/Isin: Damage Assessment during the Fara Regional Survey Project FARSUP, Sumer LXIV, 35-48

Peyronel, L./A. Vacca (2015): Northern Ubaid and Late Chalcolithic 1-3 periods in the Erbil Plain. New insights from recent researches at Helawa, Iraqi Kurdistan, Origini 37, 89-128

Peyronel, L./A. Vacca/G. Zenoni (2016): Helawa: A new Northern Ubaid/Late Chalcolithic site in the Erbil Plain, in: K. Kopanias/J. MacGinnis (eds.), 309-322 
Pittman, H./M. J. Blackman (2016): Mobile or stationary: Chemical analysis of clay administrative devices from Tell Brak in the Uruk Period, Journal of Archaeological Science: Reports 7, 877-883

Postgate, J.N. (1994): How many Sumerians per hectare? Probing the anatomy of an early city, Cambridge Archaeological Journal 4, 47-65

Pournelle, J. (2003): Marshland of cities. Deltaic landscapes and the evolution of early Mesopotamian civilization. PhD dissertation, University of California, San Diego

- (2007): KLM to Corona: A bird's-eye view on the cultural ecology and early Mesopotamian urbanization, in: E. Stone (ed.), Settlement and society. Essays dedicated to Robert McCormick Adams. Los Angeles, 29-61

Rante, R./A. Collinet (2013): Nishapur revisited. Stratigraphy and ceramics of Qohandez. Oxford

Ristvet, L. (2017): "Assyria” in the third millennium BCE, in: E. Frahm (ed.), A companion to Assyria. New York, 35-56

Rost, S. (2017): Water management in Mesopotamia from the sixth till the first millennium B.C., Water 4, 1-23

Skuldbøl, T. B. B./C. Colantoni (2016): Early urbanism on the margins of Upper Mesopotamia. Complex settlement patterns and urban transformations on the Rania Plain in Northeastern Iraq, in: Iamoni (ed.) (2016b) 1-26

Smith, M. E. (2014): How can archaeologists identify early cities? Definitions, types, and attributes, in: D. Krausse et al. (eds.), Individualization, urbanization and social differentiation. Intellectual and cultural streams in Eurasia (800-400 BC). Cambridge, 153-168

Smith, M. L. (2014): The archaeology of urban landscapes, Annual Review of Anthropology 43, 307-323

Staubwasser, M./H. Weiss (2006): Holocene climate and cultural evolution in late prehistoric-early historic West Asia, Quaternary International 66, 372-387

Stein, G. J. (2012): The development of indigenous social complexity in Late Chalcolithic Upper Mesopotamia in the 5th-4th millennia BC. An initial assessment, Origini 34, 125-151

- (2015): Tony Wilkinson (1948-2014), Iraq 77, 1-3

Stein, G. J./R. Bernbeck/C. Coursey/A. McMahon/N. F. Miller/A. Misir/J. Nicola/H. Pittman/S. Pollock/H. Wright (1996): Uruk colonies and Anatolian communities. An interim report on the 1992-1993 excavations at Hacinebi, Turkey, American Journal of Archaeology 100, 205-260

Stein, G. J./M. S. Rothman (1994): Chiefdoms and early states in the Near East. The organizational dynamics of complexity. Monographs in World Prehistory 18. Madison

Steinkeller, P. (1991): The administrative and economic organization of the Ur III state: the core and the periphery, in: McG. Gibson/R. D. Biggs (eds.), The organization of Power: Aspects of bureaucracy in the ancient Near East. SAOC 46. Chicago, 15-34

- (2001): New light on the hydrology and topography of southern Babylonia in the third millennium, Zeitschrift für Assyriologie und Vorderasiatische Archäologie 91, 22-84
- (2007): City and countryside in third-millennium southern Babylonia, in: E. C. Stone (ed.), Settlement and society. Essays dedicated to Robert McCormick Adams. Los Angeles, 185-211

- (2015): The employment of labor on national building projects in the Ur III period, in: P. Steinkeller/M. Hudson (eds.), Labor in the ancient world. A colloquium held at Hirschbach (Saxony), April 2005. The international scholars conference on ancient Near Eastern economies 5. Dresden, 137-236

Stone, E. C. (2008): Patterns of looting in southern Iraq, Antiquity $82,125-138$

- (2013): The organization of a Sumerian town. The physical remains of ancient social systems, in: H. Crawford (ed.), The Sumerian world. London, 156-177

Stone, E. C./P. Zimansky (2004): The anatomy of a Mesopotamian city. Survey and soundings at Mashkan-Shapir. Winona Lake

Trigger, B. G. (2003): Understanding early civilizations. A comparative study. Cambridge

Tsouparopoulou, C. (2013): A reconstruction of the Puzriš-Dagan central livestock agency, Cuneiform Digital Library Journal 2, 1-15

Ur, J. (2006): Google Earth and archaeology, The Society of American Archaeology Archaeological Record 6, 35-38

- (2013a): Spying on the past. Declassified intelligence satellite photographs and Near Eastern landscapes, Near Eastern Archaeology 76, 28-36

- (2013b): Patterns of settlement in Sumer and Akkad, in: $\mathrm{H}$. Crawford (ed.), The Sumerian world. London, 131-155

Ur, J./M. Ertsen (2015): Tony Wilkinson and the water history of the Near East, Water History 7, 377-379

Weiss, H. (2017): 4.2 ka BP megadrought and the Akkadian collapse, in: H. Weiss (ed.), Megradrought and collapse. From early agriculture to Angkor. Cambridge, 93-160

Widell, M./C. Hritz/J. Ur/T. J. Wilkinson (2013): Land use of the model communities, in: T. J.Wilkinson et al. (ed.), 56-80

Wilkinson, T. J. (2003): Archaeological landscapes of the Near East. Tucson

Wilkinson, T. J./McG. Gibson/M. Widell (ed.) (2013): Models of Mesopotamian landscapes. How small-scale processes contributed to the growth of early civilizations. BAR International Series 2552. Oxford

Wilkinson, T. J./L. Rayne/J. Jotheri (2015): Hydraulic landscapes in Mesopotamia. The role of human niche construction, Water History 7, 397-418

Wilkinson, T. J./J. Ur/C. Hritz (2013): Settlement Archaeology of Mesopotamia, in: T. J.Wilkinson et al. (ed.), 34-55

Wilson, K. (2012): Bismaya. Rediscovering the lost city of Adab. Oriental Institute Publication 138. Chicago

Wright, H. (1981): The southern margins of Sumer. Archaeological survey of the area of Eridu and Ur, in: R. M. Adams (ed.), Heartland of cities. Surveys of ancient settlement and land use on the central floodplain of the Euphrates. Chicago, 295-345

Zettler, R. (1993): Nippur, Volume 3: Kassite Buildings in Area WC-1. Oriental Institute Publication 111. Chicago 
Tab. 1. List of excavation and survey projects carried out by expeditions in the QADIS survey area prior to 1996

\begin{tabular}{|c|c|c|c|}
\hline YEARS & AREA/SITE & INSTITUTION & REFERENCES \\
\hline 1902 & $\begin{array}{l}\text { Bismaya/Adab to Fara/ Shurup- } \\
\text { pak (survey) }\end{array}$ & Deutsche Orient-Gesellschaft & Andrae 1903 \\
\hline $1902-1903$ & $\begin{array}{l}\text { Tell Abu Hatab/Kisurra (excava- } \\
\text { tion) }\end{array}$ & Deutsche Orient-Gesellschaft & Heinrich/Andrae 1931 \\
\hline $1903-1905$ & Bismaya/Adab (excavation) & University of Chicago & Banks 1912; Wilson 2012 \\
\hline $1925-1926$ & Whole area (survey) & $\begin{array}{l}\text { Yale University - Goucher } \\
\text { College }\end{array}$ & Dougherty 1926 \\
\hline 1968 & Whole area (survey) & $\begin{array}{l}\text { State Board of Antiquities and } \\
\text { Heritage (SBAH) }\end{array}$ & Al-Shukri 1974 \\
\hline $1968-1975$ & Whole area (survey) & University of Chicago & Adams/Nissen 1972; Adams 1981 \\
\hline 1973 & Fara/Shuruppak (survey) & $\begin{array}{l}\text { British School of Archaeology } \\
\text { in Iraq }\end{array}$ & Martin 1983; 1988 \\
\hline 1977 & Umm al-Hafriyat (excavation) & University of Chicago & Gibson $1977 / 78$ \\
\hline 1988 & Tell Dlehim/Tummal? (survey) & Kokushikan University, Tokyo & Anonymous 1989 \\
\hline
\end{tabular}

Tab. 2. List of excavations carried out by the Iraqi SBAH in the QADIS survey area.

\begin{tabular}{llll}
\hline YEARS & AREA/SITE & DIRECTOR & REFERENCES \\
\hline 1996 & Tell Dhuhaia & Muhameed Yahia Radh & Unpublished \\
2000 & Bismaya/Adab & Al Doori & Al-Doori et al. 2001-2002 \\
2007 & Tell Drehem/Puzrish-Dagan & Ali Obeed Shalkham & Al-Mutawalli/Shalkham 2014; \\
& & & Al-Mutawalli et al. 2017 \\
2011 & Tell Ruejeh & Ibraheem Mohameed & Unpublished \\
2011 & Tell Mirza & Basim Kadhem & Unpublished \\
2011,2013 & Tell Delmej 1 & Ali Obeed Shalkham & Unpublished \\
$2012-2013$ & Tell Delmej 2 & Ali Obeed Shalkham & Unpublished \\
2013 & Tell al-Akhader & Adil Kadhem Amen & Unpublished \\
2013 & Tell Abu Edan & Basim Kadhem & Unpublished \\
$2014-2015$ & Tell el-'Arris & Raad Hameed & Unpublished \\
\hline
\end{tabular}


Tab. 3. Satellite imagery and topographic maps used to create the base map for the QADIS survey project.

\begin{tabular}{|c|c|c|c|c|c|}
\hline NAME & TYPE & DATE(S) & RESOLUTION & $\begin{array}{l}\text { QUALITY OF } \\
\text { INFORMATION }\end{array}$ & SOURCE \\
\hline $\begin{array}{l}\text { Bing Maps Tile } \\
\text { System }\end{array}$ & Satellite & 2016 & Variable & $\begin{array}{l}\text { High detail. Local } \\
\text { scale }\end{array}$ & https://www.bing.com/maps \\
\hline $\begin{array}{l}\text { ESRI World } \\
\text { Imagery }\end{array}$ & Satellite & 2008 & Variable & $\begin{array}{l}\text { High detail. Local } \\
\text { scale }\end{array}$ & Through ArcGISC \\
\hline Landsat & Satellite & $1972-2016$ & $60 \mathrm{~m}$ to $30 \mathrm{~m}$ & $\begin{array}{l}\text { Medium-high detail. } \\
\text { Local scale }\end{array}$ & https://earthexplorer.usgs.gov/ \\
\hline $\begin{array}{l}\text { Declassified } \\
\text { CORONA }\end{array}$ & Satellite & 1968-1969 & $2-3 \mathrm{~m}$ & $\begin{array}{l}\text { Medium-high detail. } \\
\text { Regional and sub-re- } \\
\text { gional scale }\end{array}$ & http://corona.cast.uark.edu \\
\hline SRTM & Satellite & 2000 & $30 \mathrm{~m}$ & $\begin{array}{l}\text { Low detail. Regional } \\
\text { scale }\end{array}$ & https://earthexplorer.usgs.gov/ \\
\hline $\begin{array}{l}\text { Soviet Military } \\
\text { Topographic } \\
\text { Maps }\end{array}$ & $\begin{array}{l}\text { Topographic } \\
\text { maps }\end{array}$ & 1970 s & $1: 200,000$ & $\begin{array}{l}\text { Low detail. Regional } \\
\text { scale }\end{array}$ & $\begin{array}{l}\text { https://maps.vlasenko.net/ } \\
\text { soviet-military-topographic- } \\
\text { map/ }\end{array}$ \\
\hline
\end{tabular}

Tab. 4. List of archaeological sites also documented by UAV (drone).

\begin{tabular}{|c|c|c|c|c|c|}
\hline SITE NAME & QADIS NO. & $\begin{array}{l}\text { SITE } \\
\text { EXTENSION }\end{array}$ & $\begin{array}{l}\text { VISIBLE } \\
\text { STRUCTURES } \\
\text { (approx.) }\end{array}$ & $\begin{array}{l}\text { RELATIVE } \\
\text { CHRONOLOGY } \\
\text { (of visible structures) }\end{array}$ & $\begin{array}{l}\text { ABSOLUTE } \\
\text { CHRONOLOGY } \\
\text { (of visible structures) }\end{array}$ \\
\hline Tell Rumah & QD117 & 17 ha & $1 \%$ & Early-Middle Uruk & 3700-3400 BCE \\
\hline Tell Umm al-Fugas & QD026 & 31 ha & $38 \%$ & Early Dynastic I & 2900-2700 BCE \\
\hline Tell Abu Hatab north & QD075b & 17 ha & $35 \%$ & Early Dynastic I-III & 2900-2350 BCE \\
\hline Bismaya/Adab & QD049 & 462 ha & $10 \%$ & Early Dynastic III & 2600-2350 BCE \\
\hline Tell el-Ahmar & QD064 & 25 ha & $5 \%$ & Akkadian-Ur III & 2350-2000 BCE \\
\hline $\begin{array}{l}\text { Tell Dlehim/ } \\
\text { Tummal? }\end{array}$ & QD038 & 36 ha & $32 \%$ & Ur III & 2100-2000 BCE \\
\hline $\begin{array}{l}\text { Tell Drehem/Puz- } \\
\text { rish-Dagan }\end{array}$ & QD015 & 80 ha & $35 \%$ & Ur III & 2100-2000 BCE \\
\hline $\begin{array}{l}\text { Tell Abu Hatab/ } \\
\text { Kisurra }\end{array}$ & QD075a & 46 ha & $4 \%$ & Ur III & 2100-2000 BCE \\
\hline Tell Mizra & QD034 & 38 ha & $21 \%$ & Parthian-Sasanian & 250 BCE-650 CE \\
\hline Tell Jidr/Karkara & QD015 & 430 ha & $35.5 \%$ & Parthian-Sasanian & 250 BCE-650 CE \\
\hline
\end{tabular}




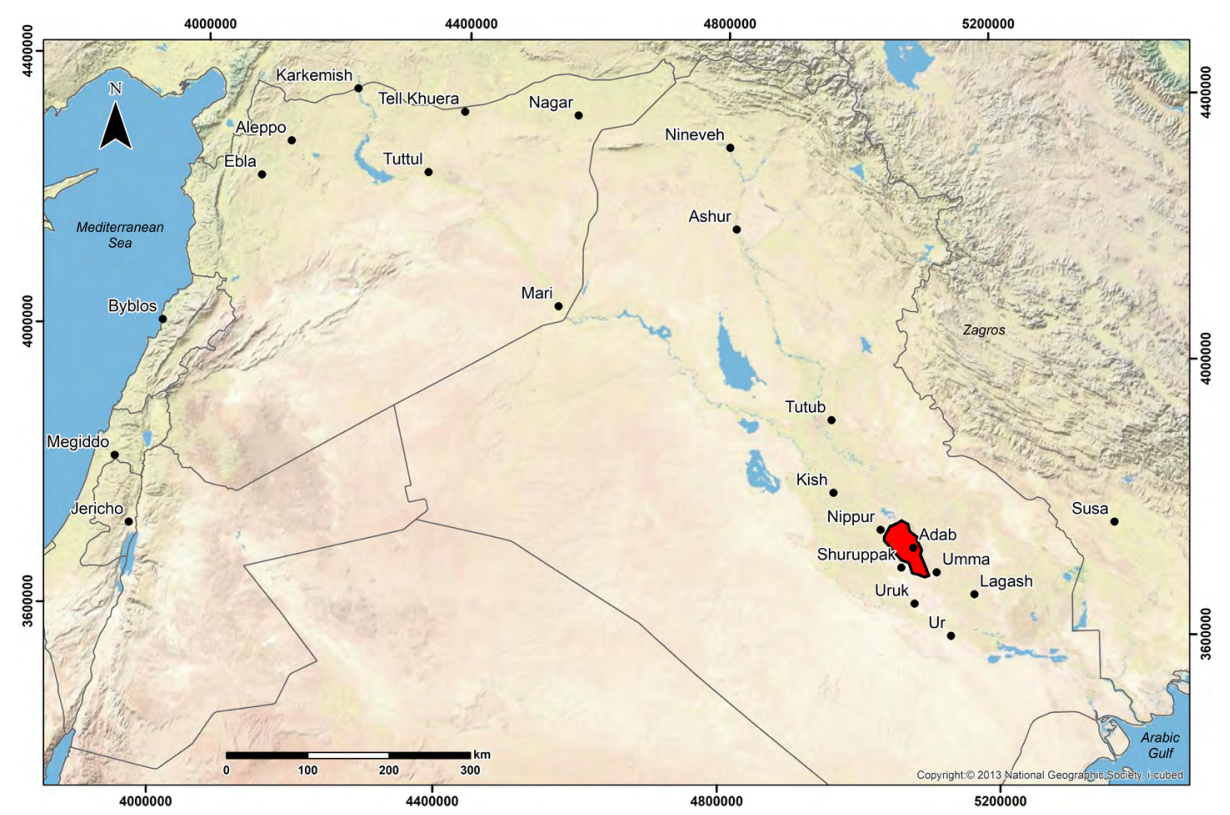

Fig. 1. The QADIS survey area.

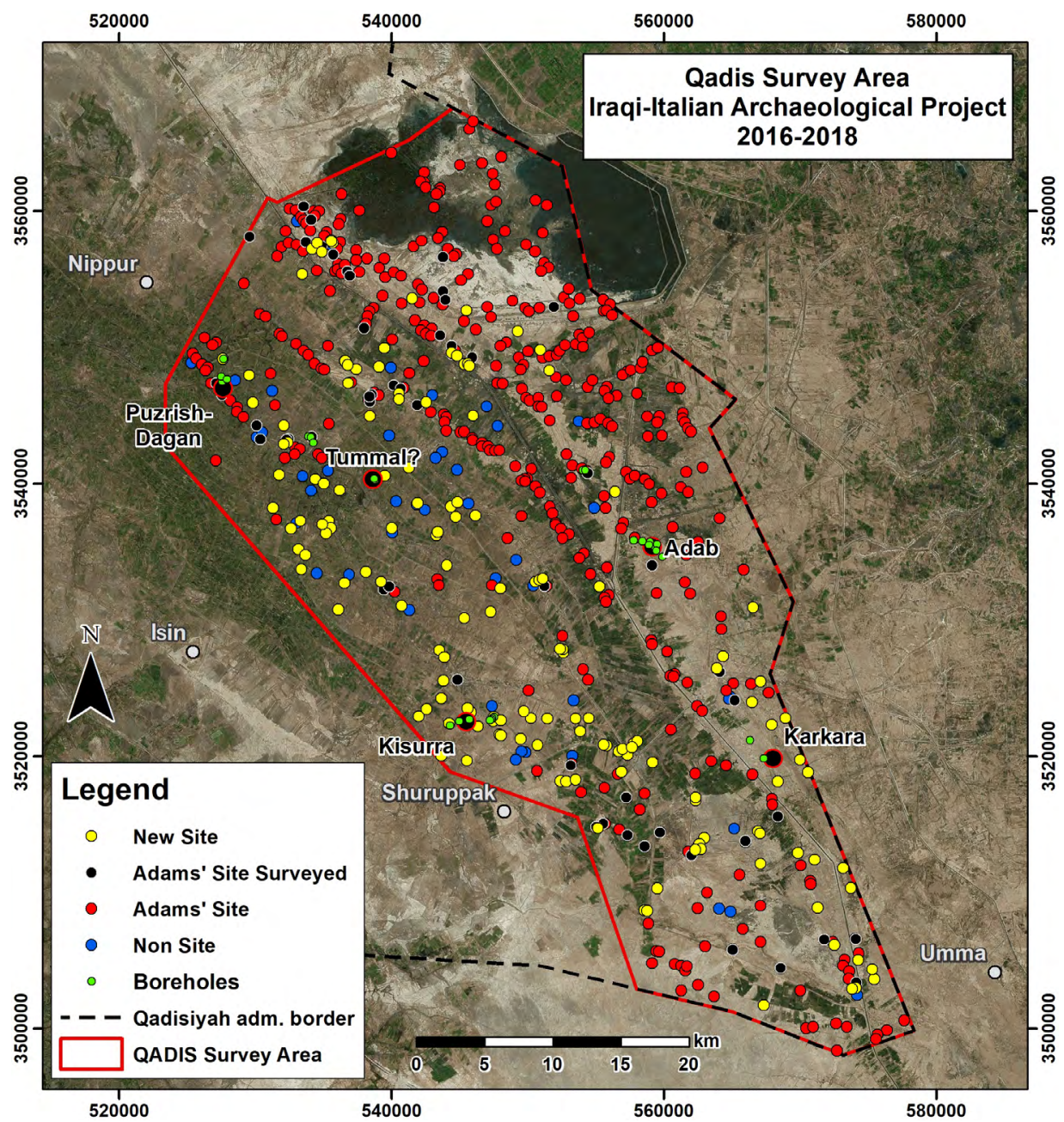

Fig. 2. The surveyed area by the QADIS project, 2016-2018. Larger dots indicate sites with a known ancient name. 

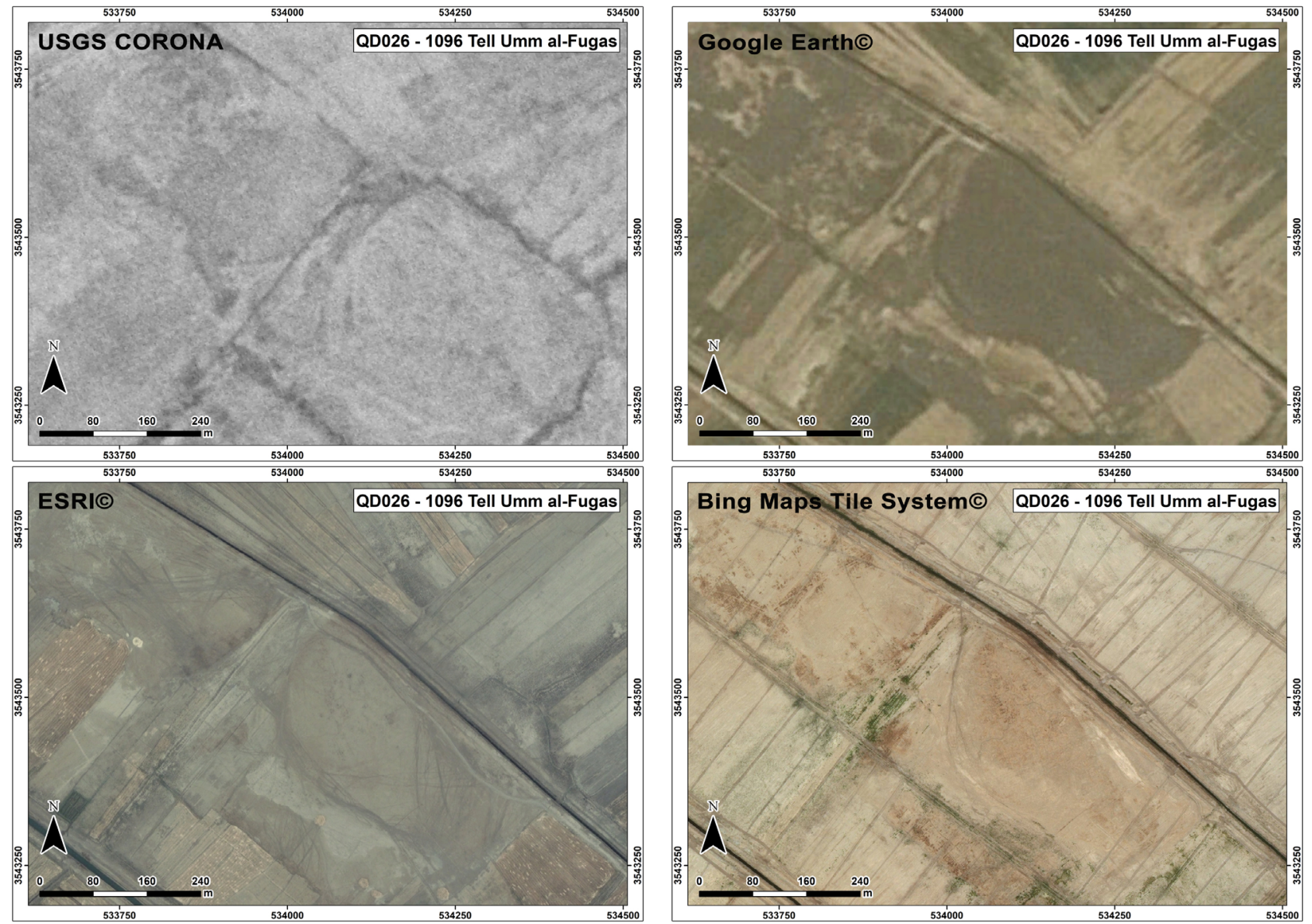

Fig. 3. QADIS survey methodology: integration of different sources to detect details in the urban layout of sites and the human impact on landscape (canals, cultivations etc.). Clockwise from top left USGS CORONA, Google Earth@, Bing Maps Tile System $\odot$ and ESRI@ satellite imagery (kindly supplied by the SBAH).
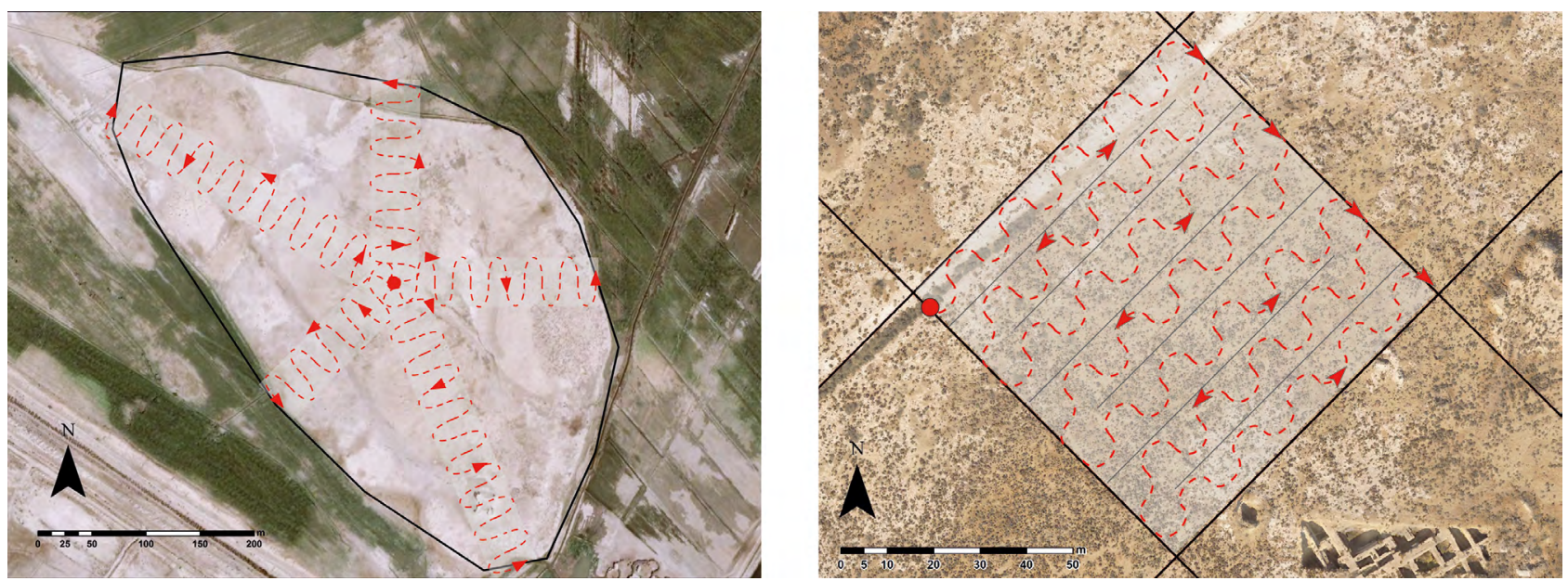

Fig. 4a-b. QADIS survey methodology. Random surface collection methodology (a) and intensive surface collection methodology (b). 


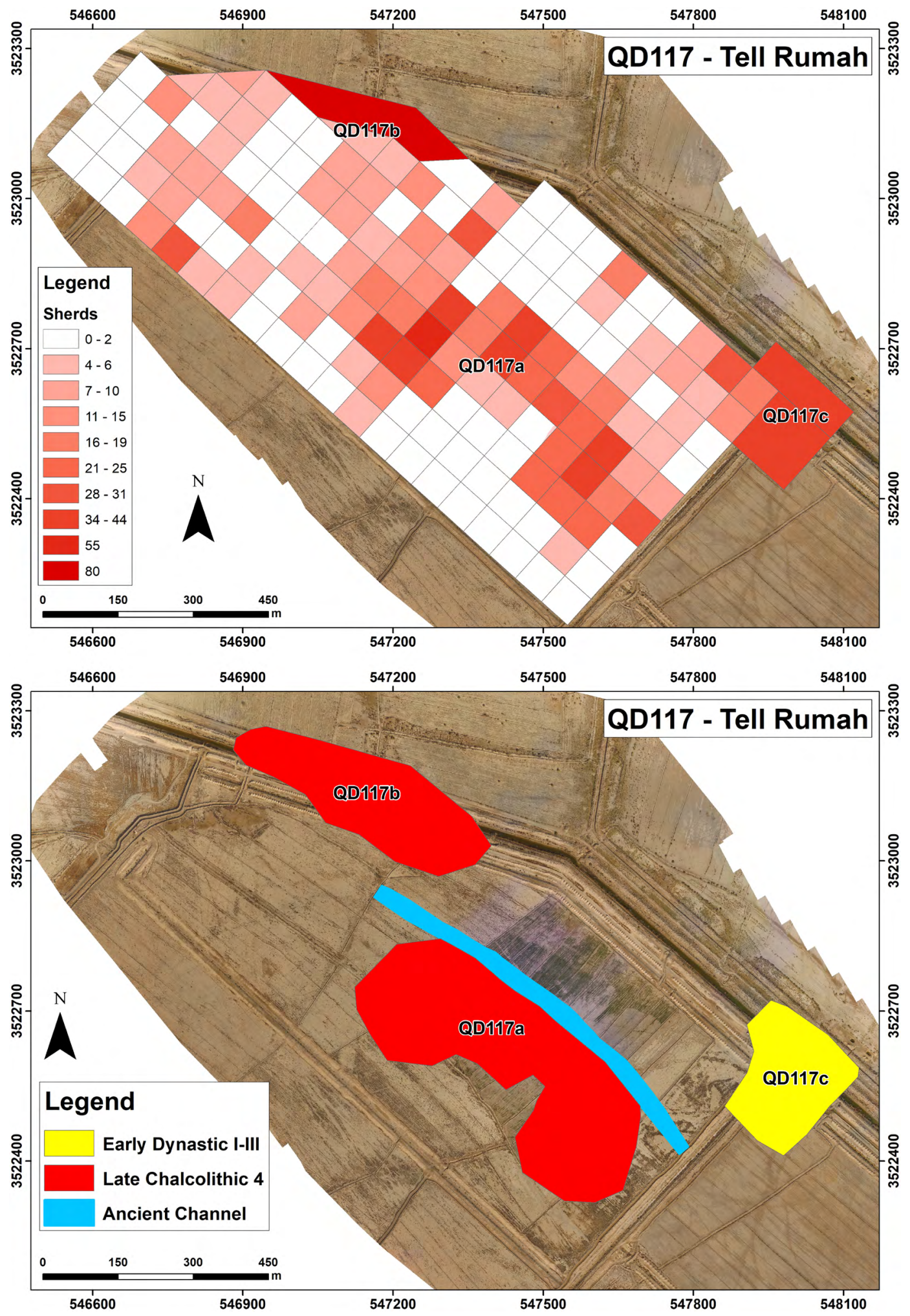

Fig. 5. QADIS survey methodology. Integrating satellite imagery, UAV as well as intensive field surveys.

The identification of a $4^{\text {th }}-3^{\text {rd }}$ millennium BCE settlement system at the newly discovered site of Tell Rumah (QD117a-c). 


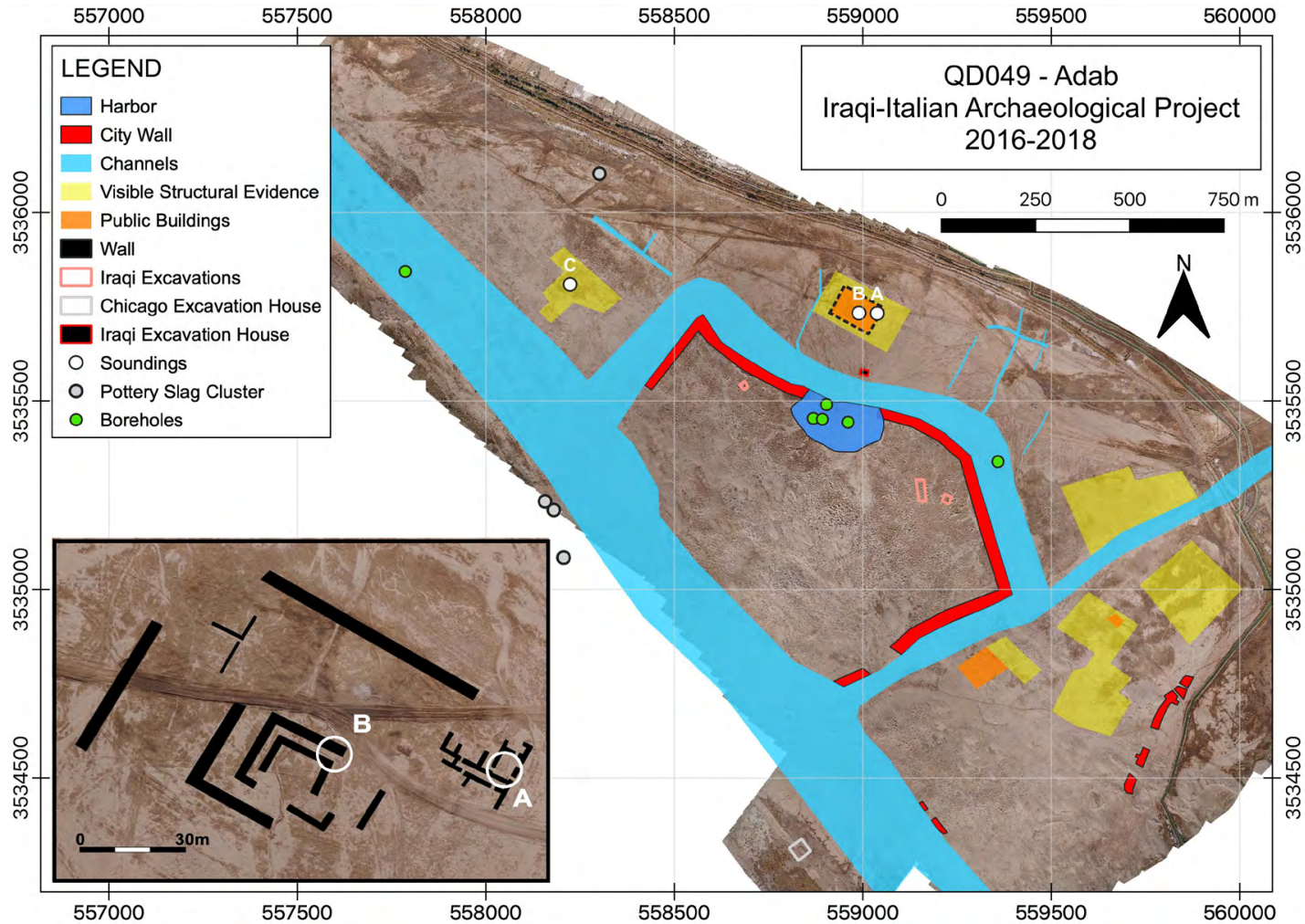

Fig. 6. Preliminary reconstruction of the urban layout and hydraulic landscape around Bismaya/Adab in the ED III and Akkadian periods (background UAV's image from taken by the QADIS project).

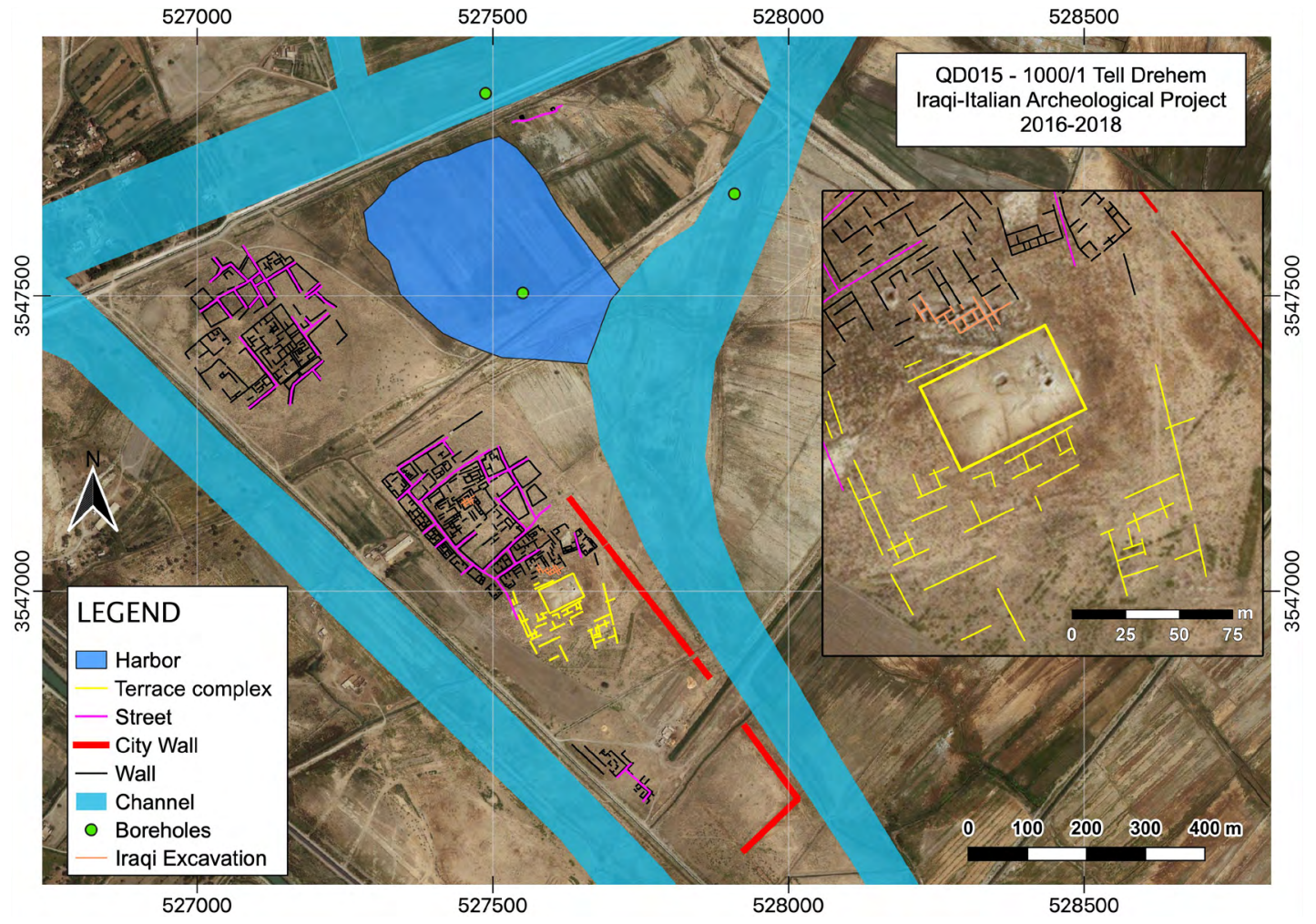

Fig. 7. Preliminary reconstruction of the urban layout and hydraulic landscape around Tell Drehem/Puzrish-Dagan in Ur III times (background Bing Maps Tile System and UAV imagery). 

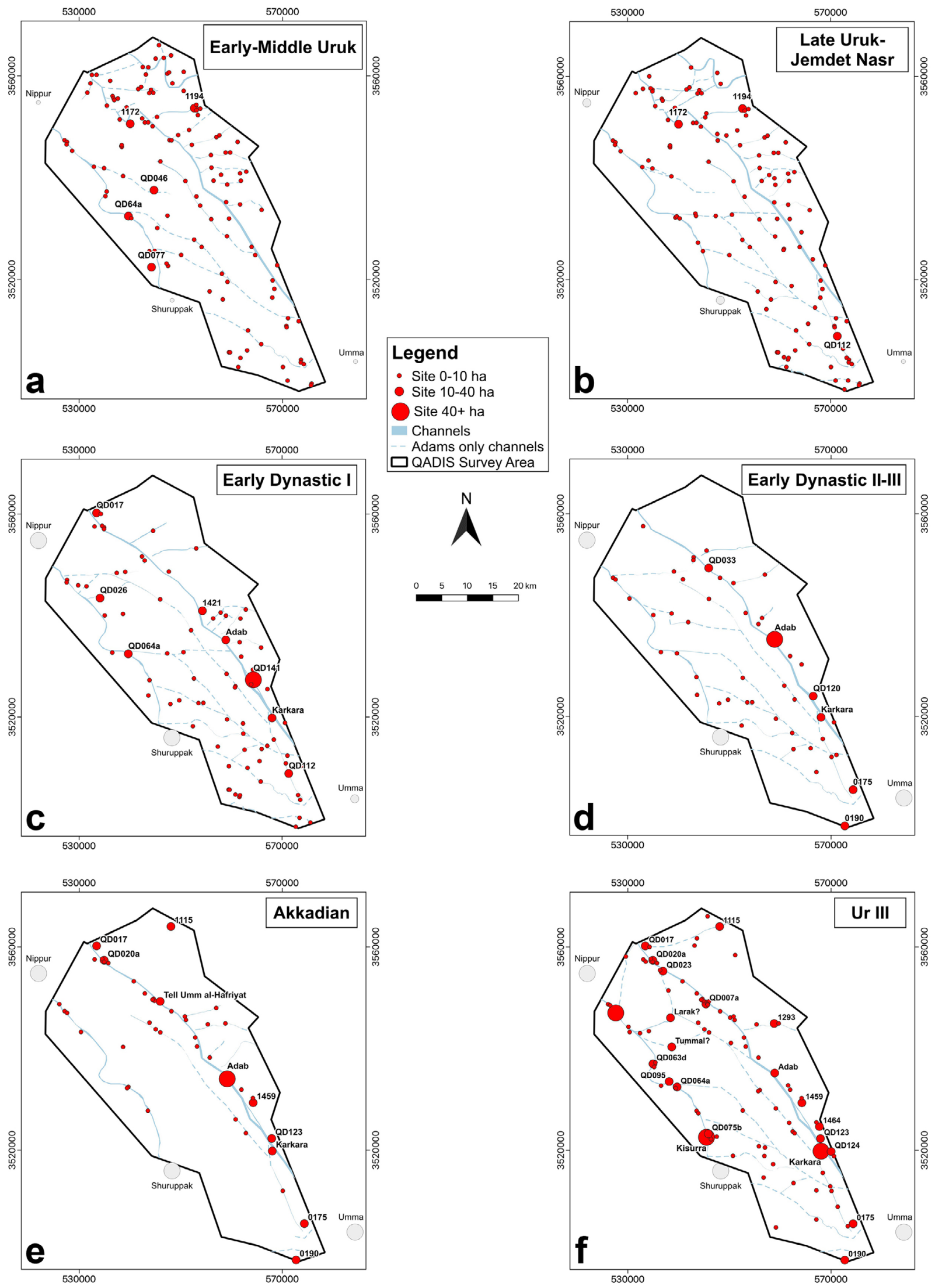

Fig. 8. Preliminary reconstruction of settlement patterns in the QADIS region through the early periods (integrated with Adams 1981; Adams/Nissen 1972): a) Early-Middle Uruk; b) Late Uruk-Jemdet Nasr; c) Early Dynastic I; d) Early Dynastic II-III; e) Akkadian; f) Ur III. 


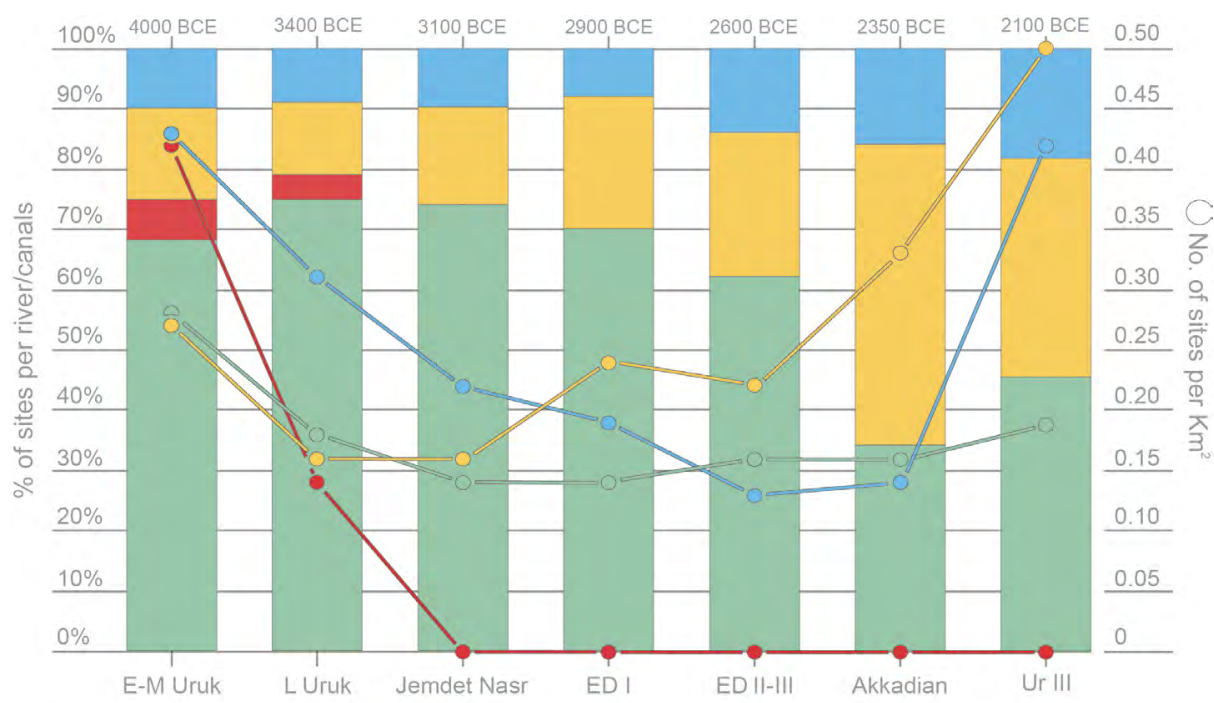

Canals

Tigris north

Tigris sourth

Euphrates

Fig. 9. Reconstructing the relation between sites distribution and waterways. Distribution of sites per $\mathrm{km}^{2}$ and percentage of sites along the two main rivers and the channel system between the Early Uruk and the Ur III period (4000-2000 BCE).

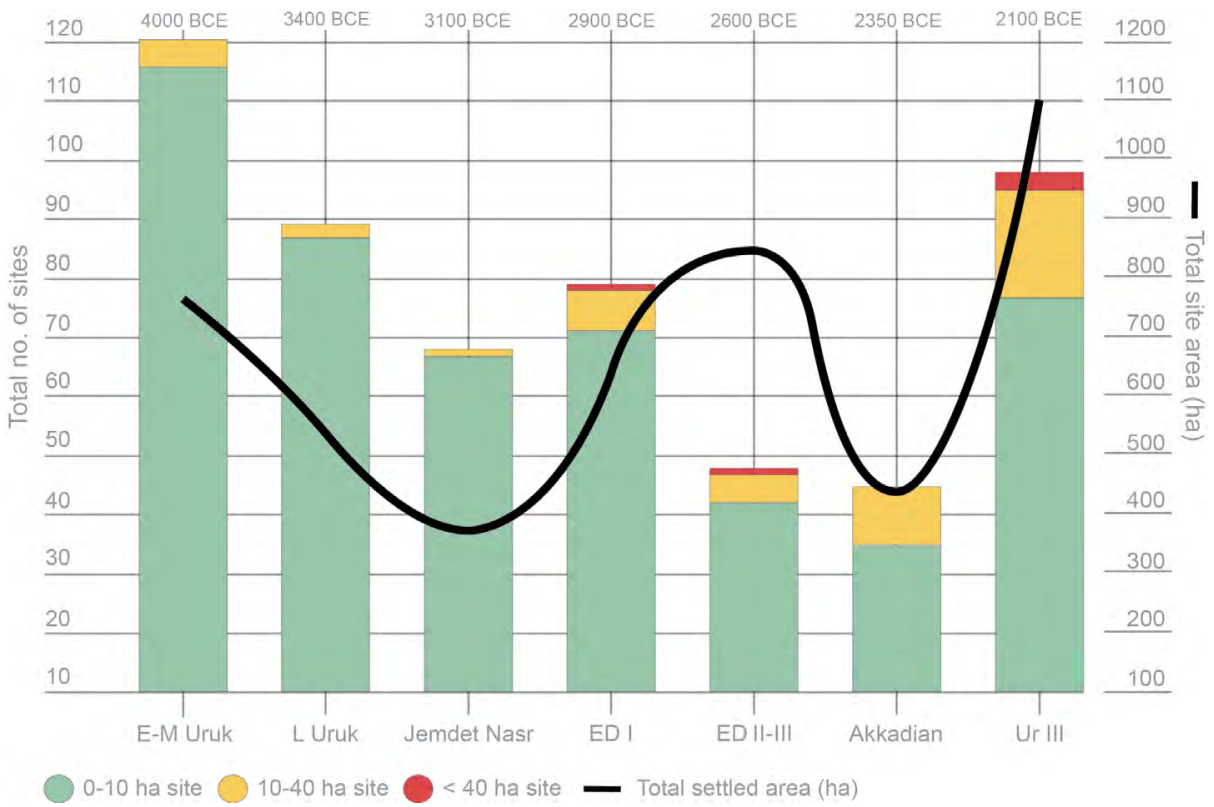

Fig. 10. Number of sites (left y-axis) and total settled area (right y-axis) in the QADIS survey area (integrated with Adams 1981; Adams/Nissen 1972). 


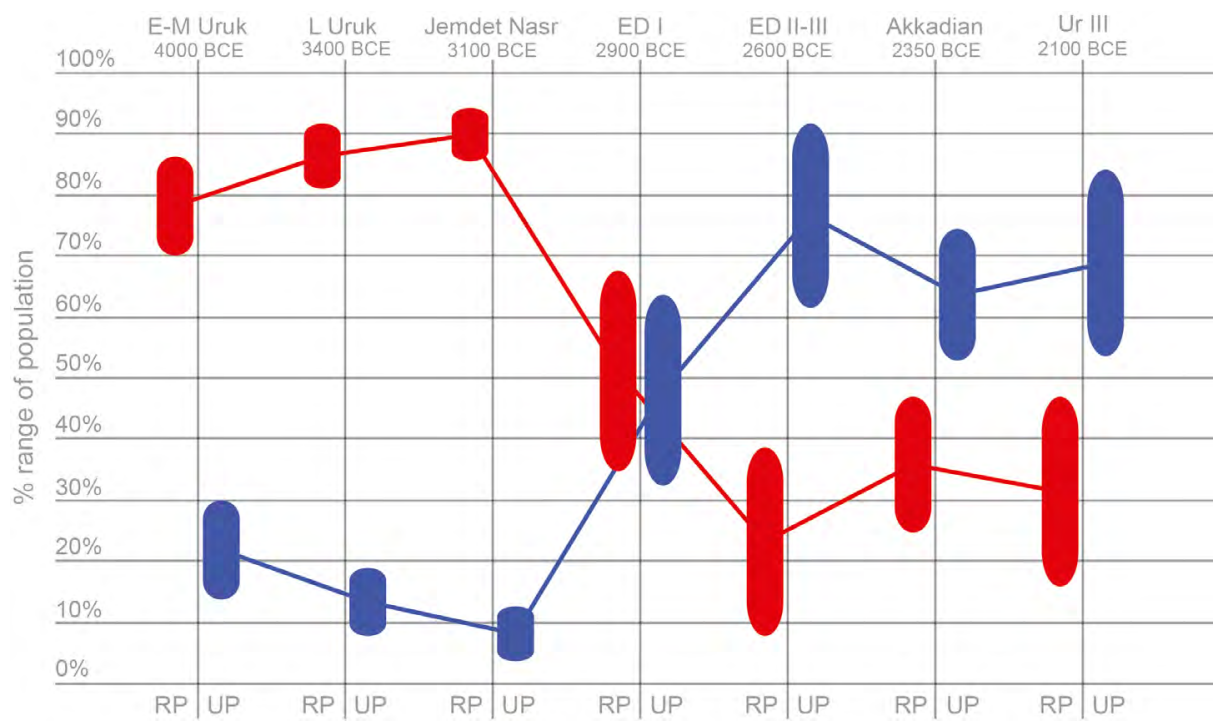

Fig. 11. Reconstructing settlement strategies in Southern Mesopotamia between $4^{\text {th }}$ and $3^{\text {rd }}$ millennium BCE: percentage range of urban population (UP) and rural population (RP) in the QADIS survey area.

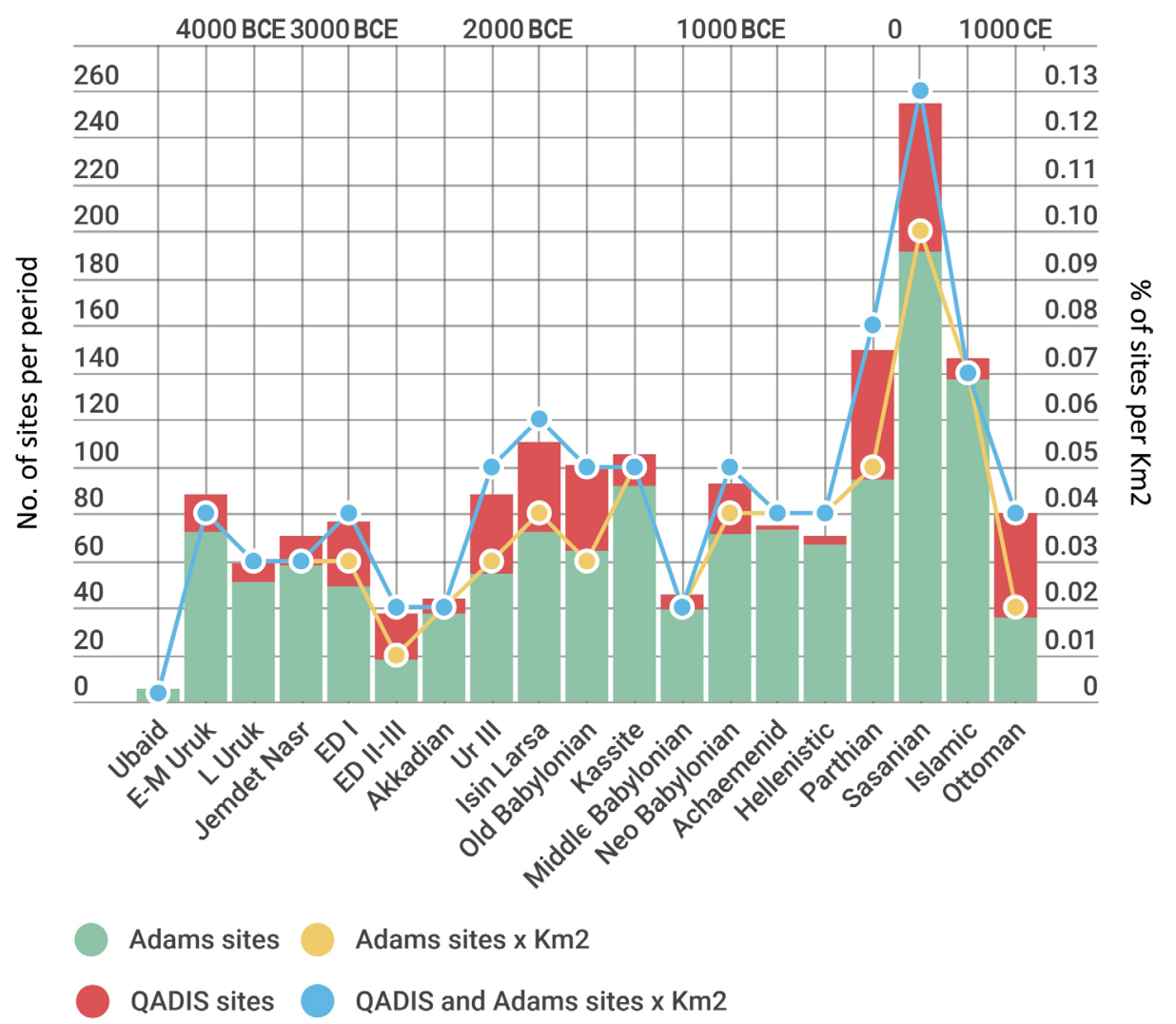

Fig. 12. Number of archaeological sites and \% of sites per $\mathrm{km}^{2}$ in the QADIS survey area according to Adams (1981; Adams/Nissen 1972) and the QADIS survey project. 